\title{
Recognition of Pleistocene marine terraces in the southwest of Portugal (Iberian Peninsula): evidences of regional Quaternary uplift
}

\author{
Paula M. Figueiredo ${ }^{1,2,{ }^{\star}}$, João Cabral ${ }^{1,2}$, Thomas K. Rockwell ${ }^{3}$ \\ ${ }^{1}$ Instituto Dom Luiz, IDL, Lisbon, Portugal \\ ${ }^{2}$ Lisbon University, Science Faculty, Geology Department, Lisbon, Portugal \\ ${ }^{3}$ San Diego State University, Geological Sciences Department, San Diego, CA, United States
}

\author{
Article history \\ Received December 30, 2012; December 20, 2013. \\ Subject classification: \\ Marine terraces, Coastal geomorphology, MIS 5, Pleistocene, Uplift, Active tectonics, Portugal.
}

\section{ABSTRACT}

Southwest mainland Portugal is located close to the Eurasia-Nubia plate boundary and is characterized by moderate seismicity, although strong events have occurred as in 1755 (Mw $\geq 8), 1969,(\mathrm{Mw}$ 7.9), and more recently in 2007 (Mw 5.9) and 2009 (Mw 5.5), all located in the offshore. No historical earthquakes with onshore rupture are known for this region. At the coastline, high sea cliffs, incised drainages, emergent marine abrasion platforms and paleo sea cliffs indicate that this region is undergoing uplift, although no morphological features were found that could be unequivocally associated with the 1755 mega earthquake. To better understand the recent tectonic activity in this sector of Iberia, it is necessary not only to analyze active structures on land, but also to search for evidence for deformation that may relate to inferred offshore active structures. We thus conducted a study of marine terraces along the coastline to identify regional vertical crustal motions. Several poorly preserved surfaces with thin sedimentary deposits, comprising old beach sediments, were recognized at elevations starting at $2 m$ elevation and rising inland up to a regional abrasion platform situated at about 120 $m$ a.s.l. We identified distinct paleo sea level references at several locations at consistent elevations. This terrace sequence is likely Late Pleistocene in age, with individual platforms correlative to MIS 5 high stands and is coherent with a long-term slow uplift of the littoral zone for the southwest of Portugal. Although dating of discrete platforms is an ongoing and difficult task, preliminary correlations of paleo-shoreline elevations suggest that the uplift rate is in the range of $0.1-0.2 \mathrm{~mm} / \mathrm{yr}$.

\section{Introduction}

The littoral section of southwest Portugal corresponds to the onshore area located close to the main known regional offshore active structures and also to the inferred source area of the 1755 earthquake $\mathrm{Mw} \geq$ 8 (estimated Mw 8.7 by Johnston [1996], or $8.5 \pm 0.3$, updated by Martínez Solares and López Arroyo [2004]. Vertical movements for the southwestern Portuguese coastal region were previously recognized as the result of a Pliocene-Pleistocene long term uplift [Feio 1951], and the first attempt to quantify the vertical rate was conducted by Cabral [1995] who estimated it to be in the range of 0.1 to $0.2 \mathrm{~mm} / \mathrm{yr}$, using an assumed Pliocene or Pleistocene age for the displaced geological markers. However, the ages of sediments were not fully constrained nor were any late Pleistocene interglacial marine terraces recognized, meaning that there was not enough control on the variability of vertical motions through time. Furthermore, no relationship was established between the observed vertical motions and active crustal structures. In what concerns the last major regional tectonic event, the 1755 earthquake, there aren't any references of littoral vertical motion associated with the earthquake in the historical accounts for the studied area, so it is unknown if there were any co-seismic effects, and if so which kind. Following the same reasoning, no recent vertical motions associated with other large historical earthquakes known for the region (such as 382 A.D.) or paleo-earthquakes are described or were identified.

In order to understand the vertical crustal motions in this region, and to better constrain the younger movements, detailed field surveys were conducted along both the western and southern coastlines for recognizing and mapping paleo sea level features and correlative beach deposits (marine terraces) that could be associated with specific global eu- 
static high stands (Marine Isotopic Stage - MIS stages). With this aim, a $60 \mathrm{~km}$-long section along the western coastline and a $40 \mathrm{~km}$-long section along the southern coastline were mapped for terrace remnants and surveyed for precise elevation. Two specific high-priority targets were delineated: one was the recognition of geological evidences of recent vertical movements along the coastline that might be associated with historical seismicity, namely with the 1755 earthquake, and the second was the recognition of the last interglacial (MIS 5e) marine terrace, which is expected to be locally preserved and emergent, even if the uplift rate is very low, because the terrace was cut at about $6 \mathrm{~m}$ above modern sea level.

\section{Regional setting}

Southwest mainland Portugal is located close to the Eurasia-Nubia plate boundary. This plate boundary can be differentiated into three distinct zones: one, a western segment, starting at the Mid-Atlantic Ridge and characterized by a transtensional WNW-ESE fault zone, the Terceira leaky transform. This zone continues eastward to a second segment, the Gloria fault, a $400 \mathrm{~km}$-long right-lateral transform fault that trends roughly E-W [Laughton et al. 1972]. Approaching the Gorringe Bank area, this linear boundary evolves to a third zone, a more complex and diffuse plate boundary [Sartori et al. 1994], with deformation being distributed among several structures that span a zone up

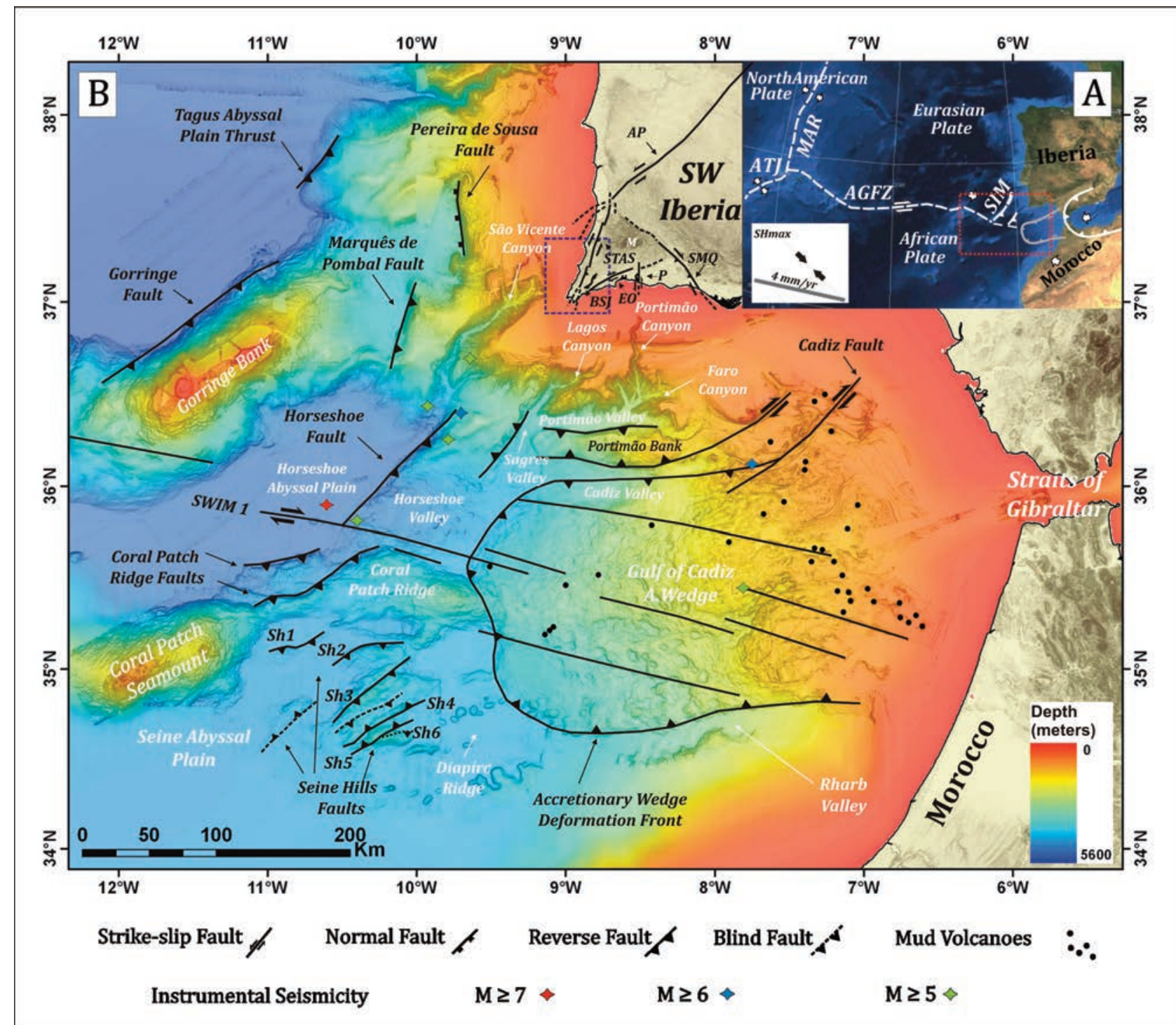

Figure 1. Main active structures and morphological features in the Southwest Iberia region according with Rosas et al. [2012] and MartínezLoriente et al. [2013] for the offshore and Dias [2001] for the onshore and their localization regarding the Eurasia-Africa plate boundary. (A): Schematic Eurasia- Africa Plate boundary for the region and localization of Figure 1 MAR - Mid - Atlantic Ridge; ATJ- Azores triple Junction; AGFZ-Azores Gloria fault zone; SIM-Southwest Iberian Margin adapted from Duarte et al. [2013], (B) Off-shore structures identified in the map; inland structures: AP-Alentejo-Placencia Fault; STASFS-São Teotónio-Aljezur-Sinceira Fault System; BSJ-Barão de São João Fault; EO-Espiche-Odiáxere Fault; P-Portimão Fault; SMQ-São Marcos-Quarteira Fault. The area studied in this work is delimited by the dashed line adapted from Rosas et al. [2012]. 
to a few hundred kilometres in width at the Gulf of Cadiz (Figure 1).

Several geophysical and geological studies have been undertaken during the past two decades to better understand this area of diffuse deformation, and the primary tectonic elements of this region [e.g. Bartolomé et al. 2012, Gràcia et al. 2003a, 2003b, Gutscher et al. 2012, Terrinha et al. 2003, 2009, Zitellini et al. 2001, 2004, 2009]. This has allowed the recognition of previously unknown relevant active structures, with some of them showing significant morphological expression, such as the Marquês de Pombal and Horseshoe thrust faults, each with conspicuous scarps that trend NNE-SSW to NE-SW. Structures in the Gulf of Cadiz trending E-W, such as those bounding the Portimão Bank (also named in some references as Gualdaquilvir Bank), and trending WNW-ESE named the Southwest Iberia Margin (SWIM) faults, which are expressed as very long lineaments in the sea floor and interpreted as strike slip faults [Zittellini et al. 2009, Duarte et al. 2011, Bartolomé et al. 2012]. More recently Martínez-Loriente et al. [2013] demonstrated that south of the SWIM faults, in the Coral Patch Ridge and Seine Hills areas at the south Gulf of Cadiz region, active NE-SW thrusts (such as North Coral Patch Ridge and South Coral Ridge faults, Seine Hill 1 and 6 faults) and WNW-ESE dextral strike slip faults (such as Lineament South and Strike slip 1 faults) deform the Holocene sedimentary unit and are therefore active structures.

The structural complexity in the Gulf of Cadiz area is the result of the long term interaction between Iberia and Nubia, where structures with different geometries and tectonic styles, mainly thrust and strikeslip, have interacted at different scales through time [Duarte et al. 2011, Duarte et al. 2013, Martínez-Loriente et al. 2013]. Geodetic data along with analysis of focal mechanisms indicate ongoing WNW-ESE IberiaNubia convergence at a rate of $4-5 \mathrm{~mm} / \mathrm{yr}$ [Fernandes et al. 2007, Nocquet and Calais 2004, Serpelloni et al. 2007, Stich et al. 2006], while geological models for the last 3 Ma point to a NW-SE convergence at roughly the same velocity [DeMets et al. 1994, 2010]. Ribeiro [2002] suggested the occurrence of sinistral rotation of the maximum horizontal compressive stress in southwest Iberia since the Pleistocene, although changes in the on-going deformation in this region are a matter of debate [Cunha et al. 2012].

The Southwest Portuguese Margin is located in the northwest sector of the Gulf of Cadiz, and is characterized by NNE-SSW to NE-SW striking thrust systems, such as the previously referred Marquês de Pombal, Horseshoe and Gorringe Bank faults. Some of these structures in this sector extend onshore, such as Alentejo-Placencia fault system [Pereira and Alves 2013] where a minor sinistral strike-slip component has been recognized offshore and the São Teotónio-Aljezur-Sinceira fault system [Terrinha 1998, Lopes 2002], where a sinistral component was also recognized but inland.

The regional instrumental seismicity corroborates the occurrence of diffuse deformation: seismicity is moderate, frequently shallower than $40 \mathrm{~km}$ and broadly distributed and focal mechanisms are dominantly thrust and strike-slip [Carrilho et al. 2004, Carrilho 2005, Stich et al. 2010]. An Ocean Bottom Seismometer (OBS) campaign undertaken in the study region for 11 months (from August 2007 to July 2008) showed that seismicity extends deeper than $40 \mathrm{~km}$, concentrating in this time period at a depth of 50-55 km [Geissler et al. 2010], corresponding to three major clusters of earthquakes that occurred in areas coinciding with the location of the three larger instrumental earthquakes for the region [Silva et al. 2010]: the $28^{\text {th }}$ February 1969 (Mw 7.9), the $12^{\text {th }}$ February 2007 (Mw 5.9), and the $17^{\text {th }}$ December 2009 (Mw 5.5) events. The focal mechanisms calculated for the three major earthquake clusters and for the OBS survey also reveal different deformation behaviours, indicating thrusting at the Marquês de Pombal fault region, and strike slip associated with the SWIM fault system in the Horseshoe plain [Bartolomé et al. 2012], consistent with the location and focal mechanism of the Mw 5.9, 2007 earthquake [Custódio et al. 2012].

Despite the tendency for the occurrence of moderate levels of seismicity, large earthquakes were generated in this area, such as the November $1^{\text {st }} 1755$ earthquake and tsunami and the Mw 7.91969 earthquake [Zittelini et al. 2009 and references within]. Large historical and paleo-earthquakes generated in the Gulf of Cadiz were also recognized by the identification of correlative tsunami deposits [Baptista et al. 2009] and turbidites [Gràcia et al. 2010], suggesting a 1300-1800 yr recurrence interval for a regional earthquake with magnitude larger than 8 .

The Marquês de Pombal fault is usually considered one of the best candidates for the generation of the 1755 tsunami [Baptista et al. 2009], and is therefore assumed to have ruptured in 1755 together with other faults, thereby producing a complex rupture. If so, the $1755 \mathrm{Mw}>8$ event is likely closely associated with the southwest Portuguese continental margin.

Several faults with evidence of Pliocene and Quaternary activity have been previously recognized onshore southwest Portugal [Feio 1951, Pereira 1990, Cabral 1995, Dias 2001, Dias and Cabral 2002], mainly through geomorphologic analyses. The majority of the 
active structures in this region trend NNE-SSW to ENE -WSW, though N-S to NW-SE faults are also present (Barão de São João, Espiche and Portimão faults), are mostly less than $20 \mathrm{~km}$ long, and show predominantly reverse and strike-slip component. Historical seismicity is known for the past 2000 years (due to Roman and Arab occupations) [Brito 1597, Lopes 1842], however no Holocene fault surface rupture was ever recognized. The active faults that are recognized have low activity rates, less than $0.1 \mathrm{~mm} / \mathrm{yr}$ [Dias 2001, Dias and Cabral 2002], and therefore long periods of seismic quiescence are expected. Instrumental seismicity is usually of low magnitude, diffuse and hard to correlate with the known Quaternary structures [Carrilho et al. 2004, Carrilho 2005].

The most representative of such active structures in the study region is the NNE-SSW, sub-vertical, $50 \mathrm{~km}$ long São Teotónio-Aljezur-Sinceira left-lateral fault system (STASFS). This fault zone extends north towards the southwestern section of the Alentejo-Plasencia fault [Cabral 1995, Villamor et al. 2012], though their spatial and temporal relationships are still not clear from the available data. STASFS trends parallel to the western coast, corresponding to the nearest known inland active brittle structure that may be related to the ongoing plate boundary deformation observed in the offshore. This fault zone deforms a ca.10 km wide regional abrasion platform that is considered to be originally of late Miocene age, and which has been reoccupied or recut during the Pliocene and the Pleistocene, implying that the capping sediments are of Quaternary age. Dias [2001] estimated a slip-rate of ca. 0.03-0.06 mm/yr for this fault zone, based on the vertical offset of morphological features. However, considering that the sense of slip on this structure is probably mainly strike-slip, those vertical separation values are likely a minimum estimate. Some authors suggest that the STASFS extends to the offshore, towards the south or southwest [Lopes 2002, Terrinha 1998, Roque 2007], but there is no unequivocal evidence to correlate the inland fault system with the morphological features inferred as the fault extension in the offshore. Detailed geomorphologic and paleoseismological studies along the STASFS [Figueiredo et al. 2011, Figueiredo et al. in preparation] indicate that its southern sector (south of Sinceira basin) does not show evidence of significant Plio-Pleistocene deformation, the fault system probably having splayed into several minor faults. In fact, several parallel faults do exist in the local Mesozoic limestone bedrock, promoting the development of karst pits, which are filled with PlioPleistocene sands (Faro-Quarteira sands) along the coastal section (Martinhal-Zavial) where the STASFS should intersect the coastline. The spatial distribution and elongated shape of those karst features suggest a structural control by a previous structural fabric on the karst development [Dias and Cabral 2002].

\section{The Southwest Portugal coastal geomorphology}

The southwestern Portuguese littoral can be subdivided in two distinct coastlines types: the first is the NNE-SSW oriented, west facing coastline which is directly exposed to the Atlantic swells, whereas the second is the ENE-WSW trending southern coast of Portugal (Figure 2). The N-S section of coast is exemplified by steep cliffs developed in highly deformed $\mathrm{Pa}$ leozoic schist and greywacke bedrock. The modern abrasion platform is narrow, around $300 \mathrm{~m}$ in width based on topographic and bathymetric maps (I.G.E.O.E. and I.H.), and the littoral zone is dominated by a rocky-shore environment, with coarse clastic sediments and thin sandy beaches present at the mouths of the main drainages and in sheltered areas, or along some linear coastal segments that locally reach some kilometers in length, but less than a few tens to a few hundred meters in width. Cliffs have steep slopes, and towards the south increase their height, reaching circa $130 \mathrm{~m}$ in elevation. Several narrow and deeply incised creeks hanging along the cliffs are also recognized. These creeks contrast with larger fluvial drainages that have broad alluvial filled valleys, which are frequent along the Portuguese coastline in general and also in this sector. Mass movements are common, favoured by the bedrock structure. An exception exists along this coastline in the Carrapateira area (Figures 2, 7 and 8), where the bedrock is composed of Jurassic limestone in the Alentejo Basin (a N-S elongated Mesozoic basin generated from the Atlantic extension; Pereira and Alves 2011). This coastal section, with cliffs reaching only $40 \mathrm{~m}$, is cut on less deformed Mesozoic bedrock where karst development has taken place and there are fewer mass movements. Cliff retreat along the western coastline varies substantially according to lithology and local structure geometry, with present rates ranging from 2.5 to $11 \mathrm{~m} / \mathrm{ka}$ in the Paleozoic schistose bedrock, to as low as $1 \mathrm{~m} / \mathrm{ka}$ in the Jurassic limestone, based on 50 years of observations [Marques 1997]. Andrade et al. [2002] have calculated that the average wave energy input for a representative site along this coastline (Monte Clérigo) reaches 40 to $45 \mathrm{kWm}-1 / \mathrm{yr}$, which is significantly higher than at a sheltered location along a south facing coastal zone near Lisbon, where a value of only 6 $\mathrm{kWm}-1$ / yr was inferred using the same methodology, corroborating that the wave energy input along the SW coastline is significantly high.

The approximately E-W oriented southern coastline 


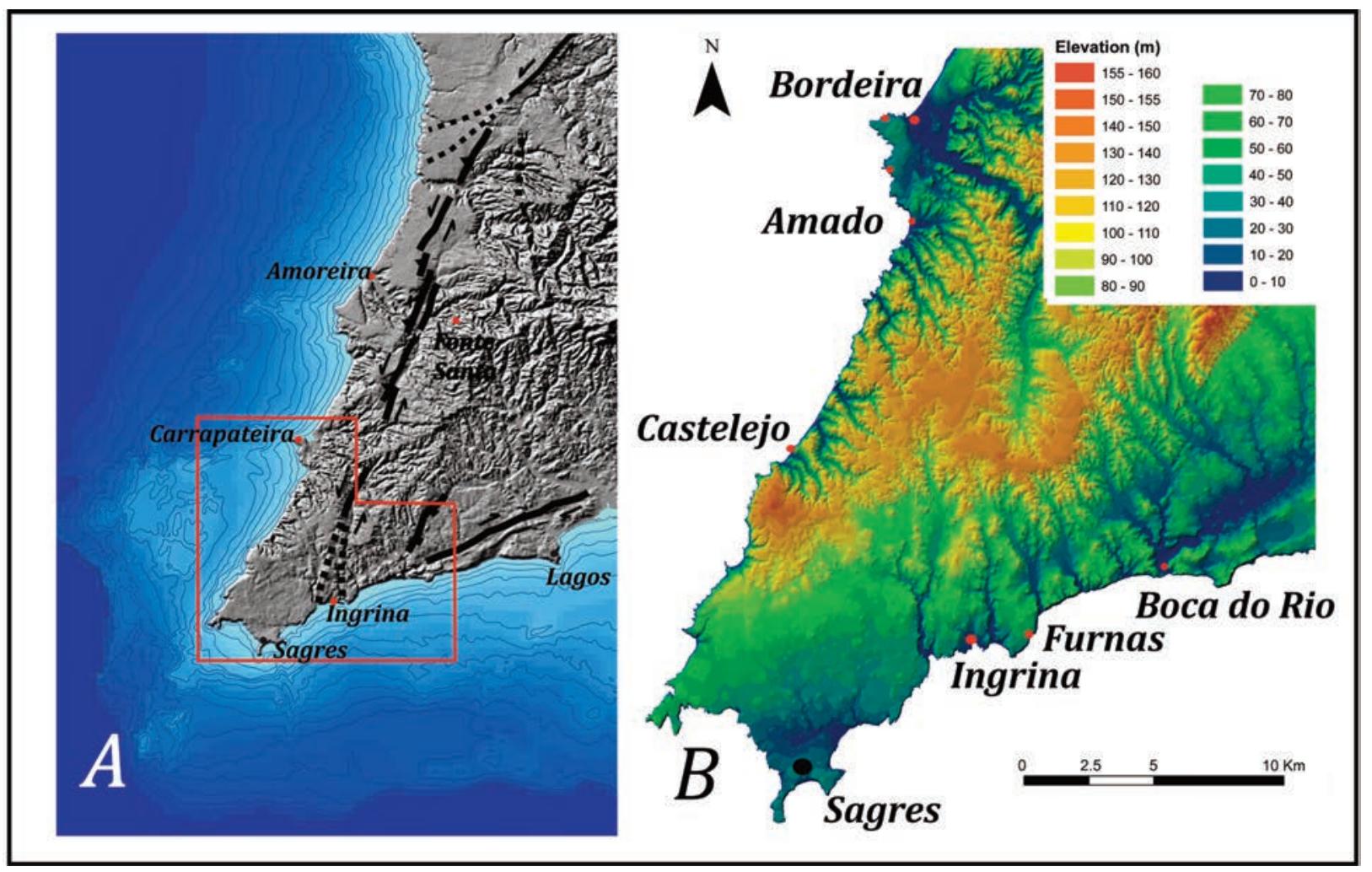

Figure 2. Digital terrain model of southwestern Portugal: (A): Regional Geomorphology with main active structures Shaded relief (SRTM) and continental shelf bathymetry (0 to $200 \mathrm{~m}$ depth, contour lines, each $10 \mathrm{~m}$ (IH); (B) Digital Terrain Model from the study area, (IGEOE topographic data). Red dots indicate marine terrace locations, black dots correspond to toponymy.

is developed on Mesozoic limestones in the west and on marls to sandy Miocene sediments towards the east. This difference in lithology, and the consequent resulting morphology, lead to an irregular and lower coastline with cliff heights reaching 50-60 $\mathrm{m}$ at Sagres in the west, and decreasing eastward to heights of about 20-30 m. Karstic features are common and sink holes are usually filled with sands. The modern abrasion platform is slightly broader here than along the $\mathrm{N}-\mathrm{S}$ coastline, also increasing in width eastward. This coastline is sheltered from north and west Atlantic swells, but more exposed to the southwest and southeast ones. Sandy beaches are common, mostly in sheltered areas in the west, but are continuously present towards the east, where dune systems also exist. Historical cliff retreat rates also vary significantly along this coastline, ranging from $0.9 \mathrm{~m} / \mathrm{ka}$ in the IngrinaFurnas sector to about $16 \mathrm{~m} / \mathrm{ka}$ at Boca do RioSalema [Marques 1997] (Figure 2). In the Carrapateira area, the limestone promontory in the west coast, coastal morphology exhibits similarities with that along the southern coastline, and retreat rates are similar to the Ingrina-Furnas sector.

Inland, the most significant geomorphologic feature corresponds to a broad regional abrasion platform cut across the Paleozoic schists. This surface is particularly well represented along the western coast, north of Sagres, where it reaches an elevation of $120-$ $130 \mathrm{~m}$. Capping beach sediments are absent in this sector of the platform, although scattered rounded quartz pebbles are commonly present. No geochronologic information is available for this surface, although the platform has been considered as possibly late Miocene in age, and reoccupied and re-trimmed during Pliocene and Pleistocene times [Feio 1951, Pereira, 1990, Dias, 2001]. It is likely that during the Plio-Quaternary, an abrasion platform was cut across older Miocene sediments, thereby developing a younger erosional abrasion platform, where Miocene sediments could be sparsely preserved beneath Plio-Quaternary capping sediments.

The highest surface with cover sediments, assumed to be marine or fluvio-marine, is present at Fonte Santa (Figure 2), located $15 \mathrm{~km}$ inland at an elevation of about $350 \mathrm{~m}$. According to Feio [1951], these sediments are correlative of a high "summitplain" which corresponds to a remnant of a Pliocene planation morphology that surrounds Mount Monchique, a Cretaceous igneous massif that reaches $900 \mathrm{~m}$ in elevation and is considered an inselberg. These marine-like sediments are overlain by aeolianites that are strongly consolidated by iron and manganese oxides and considered to be Pliocene in age [Manuppella 1992], again implying that all lower ter- 
races have been refreshed or re-cut after this time.

Towards the southeast, the regional erosion surface transitions to several discrete surfaces cut into the Mesozoic sandstone, marl and limestone bedrock of the Algarve Basin [Pereira 1990], which may actually correspond to a sequence of closely spaced, poorly preserved, middle Pleistocene marine terraces. This is very similar to the middle Pleistocene Linda Vista terrace set of southern California, which transitions from a very broad $(>10 \mathrm{~km})$ abrasion surface at San Diego to a sequence of discrete, narrow (50-200 m-wide) marine terraces northward towards Los Angeles, primarily as a function of bedrock resistance to erosion [Kern and Rockwell 1992].

\section{Identification of references for characterizing ver- tical movements}

\subsection{The present reference}

The present tidal range in Portugal is meso-tidal within a 2 to $4 \mathrm{~m}$ maximum range, and with the maximum high-tide at circa $2 \mathrm{~m}$ m.s.l. For characterization of the elevation of the modern wave-cut platform and associated beach deposits in this region, one must take into account this tidal range, as most terrace cutting likely occurs during storms at high tide. As expected, other features in this area, such as notches and sea caves, will also reflect this tidal range and present larger dimensions [Wziatek et al. 2011] than equiva-
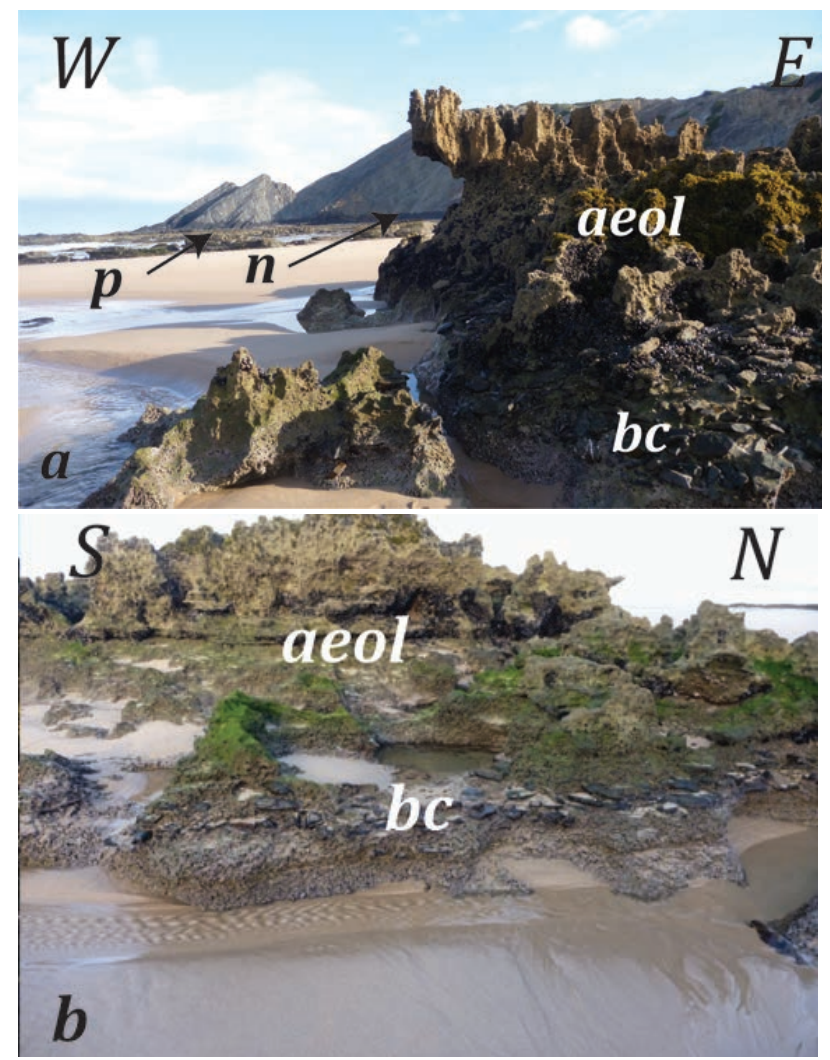

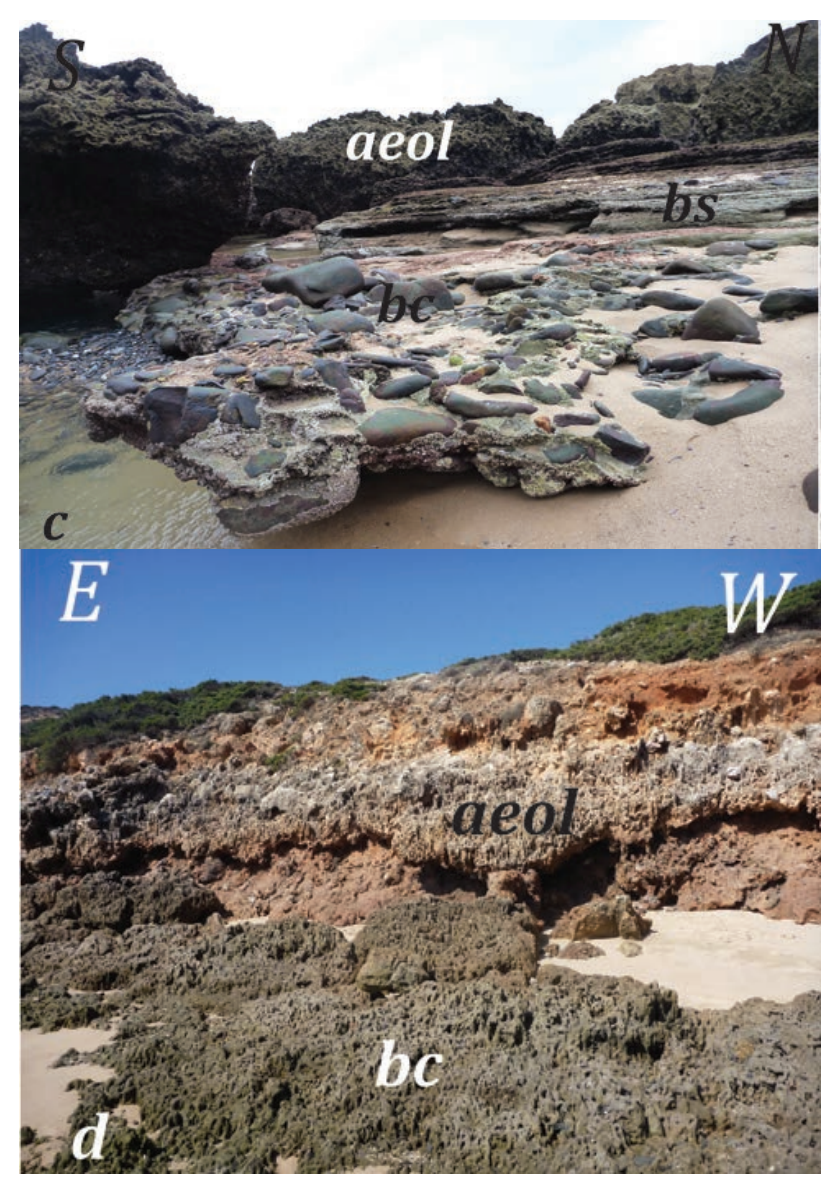

Figure 3 (counterclockwise from down left). The modern abrasion platform is reoccupying an older one at several sites in the southwest Portuguese coastline. All of these sites share the same sedimentary sequence, and the paleo-shorelines are at the same elevation. a) Perspective at Amoreira beach; in the background the abrasion platform is cut into schists. Overlying the abrasion platform (p), now reoccupied by the nowadays sea level are basal coarser sediments (bc) and aeolianites (aeol), with a notch (n) developed at the back edge. b) Another perspective from Amoreira beach, aeolianites (aeol) on top of basal coarser sediments (bc). c) Castelejo beach, coarser basal sediment (bc), interbedded with medium to fine sand, overlying an abrasion platform (not visible in this image, covered by modern beach sand) and underlying aeolianites (aeol); d) Bordeira beach, basal coarser sediments (bc), underlying several aeolianite (aeol) units.

lent features that form in regions of micro-tidal ranges, such as in the Mediterranean Sea, and their mean elevation fluctuates within the tidal range. The coastline is frequently hit by storms generated at long distances in the Atlantic [Costa et al. 2001], and the wave energy during such storms is commonly quite high, resulting in the formation of storm benches and storm notches. The shoreline angle elevation reflects not only the tidal range, the wave energy impact, and the bedrock resistance, but also the smaller scale coastal physiography (if it is a bay or an exposed cliff) and, therefore, the shoreline angle elevation fluctuates within a range up to a few meters from the mean sea level [Wright 1970]. Assuming that the resulting effect from all these variables has not changed significantly since the Pleistocene, it is therefore crucial to under- 
stand the local modern processes involved in the development of a wave-cut abrasion platform, along with the cliff and beach system, to properly interpret the past and correctly interpret the elevations of paleo features. We discuss this further below in the section on field interpretations.

As referred above, in this work we will focus on the surfaces and features associated with sea-level that we expect to be the youngest, or attributable to recent vertical movements. Secondly, we discuss observations that pertain to a possible uplift or subsidence signal associated with historical seismicity.

\subsection{Recognition of paleo marine terraces}

The morphological recognition of paleo marine terraces follows the nomenclature of Bradley and Griggs [1976]. According to these authors, most platforms can be described as having three different segments: an offshore or outer edge segment with a generally low gradient, a near-shore segment, with an intermediate gradient, and a shoreline segment characterized by a steeper gradient adjacent to the inner edge at the paleo-shoreline. Thus, a single marine terrace can exhibit these different surface segments, and distinct morphological elements, all generated with the sea at the same level. This differentiation may vary locally, especially with lithology resistance, wave energy incidence and coastal morphology. In the present study we infer the original elevation of the platform segments and of other morphological elements based upon the elevation of their modern analogues.

Paleo sea level features related to past sea level high stands, such as raised marine terraces, are present along the western and the southern coastlines, albeit in a discontinuous pattern. In general, the marine terraces or wave-cut platforms are poorly preserved, beach sediments are mostly eroded and, locally, younger aeolianites cover the entire morphology, making it difficult to recognize the terraces and to distinguish them from other features. Along the cliffs in the Paleozoic schists, lower elevation features that are expected to be correlated with the late interglacial (MIS 5) are mostly absent, since they have been mostly or completely removed by the Holocene transgression and erosion. In areas of limestone cliffs, which are even more resistant to erosion, paleo sea level features at lower elevations are better represented, although they are still poorly preserved in most areas. To understand the regional marine terrace patterns and to establish a regional sequence, consistent observations from several sites are needed, along with their tentative correlations. We will present a brief description of the mentioned sites, describing each of the recognized surfaces, and discuss their inferred ages later.

For detailed geomorphological analyses, topographic surveys were conducted using a DGPS-RTK (Leica GPS1200), with a vertical error smaller than 10 $\mathrm{cm}$. All elevations presented correspond to elevations above mean sea level.

\subsubsection{Ingrina beach}

Located along the southern coastline (Figures 2 and 4), the Ingrina beach is located in a small and confined bay, $200 \mathrm{~m}$ in width and $300 \mathrm{~m}$ in length, cut into Jurassic limestone. At this site, several surfaces are interpreted as paleo wave-cut platforms, and are preserved in a sequence along with their respective paleo-sea cliffs. The modern wave-cut platform, T0, is developed at the infra-tidal, tidal, and supra tidal zone, and is mostly recognized in the submarine section and during very low tides. The beach has fine to medium sand, and the inner edge is usually covered by beach and aeolian sediments at an elevation of about 2 to $3 \mathrm{~m}$ (white line in Figure 4).

A bench at 3-4 m elevation corresponds to the modern storm boulder accumulation. At a sheltered section along the eastern side of the bay, paleo sea caves and a possible level of bioerosion, inferred by the presence of round borings that develop perpendicular to the surface and are assumed to be Lithophaga borings, occurs at 2.8 to $3.8 \mathrm{~m}$. No correlative sediments are preserved at this elevation.

A well-preserved bedrock surface at 6 to $8 \mathrm{~m}$ elevation is recognized primarily along the western side of the bay. Although this surface is very well preserved, it shows a scarce sedimentary cover. The elevation of the shoreline or inner-edge varies from 6 to $7 \mathrm{~m}$ along the southern, ocean-ward section of this surface, and reaches a maximum elevation of $8 \mathrm{~m}$ at the cuspate landward back-edge of the bay, similar to the modern shoreline. We refer to this terrace as T1 (blue line in Figure 4).

Another surface cut into the limestone bedrock at circa $12 \mathrm{~m}$ elevation is a striking feature at Ingrina, and it is visible mainly along small spurs on both sides of the bay. This surface expressed along the spurs is generally flat or shows a low gradient, and smoothly ramps up to a higher elevation farther inside the bay, ranging then between $12 \mathrm{~m}$ and $16 \mathrm{~m}$ elevation. It has pedogenic carbonate locally capping the abrasion surface along with locally preserved cemented littoral sediments. Sandy sediments are scarcely preserved (except where cemented by carbonate), but round quartz pebbles are scattered ubiquitously on the surface. Another surface is present at elevations ranging from 16 to $18 \mathrm{~m}$, 

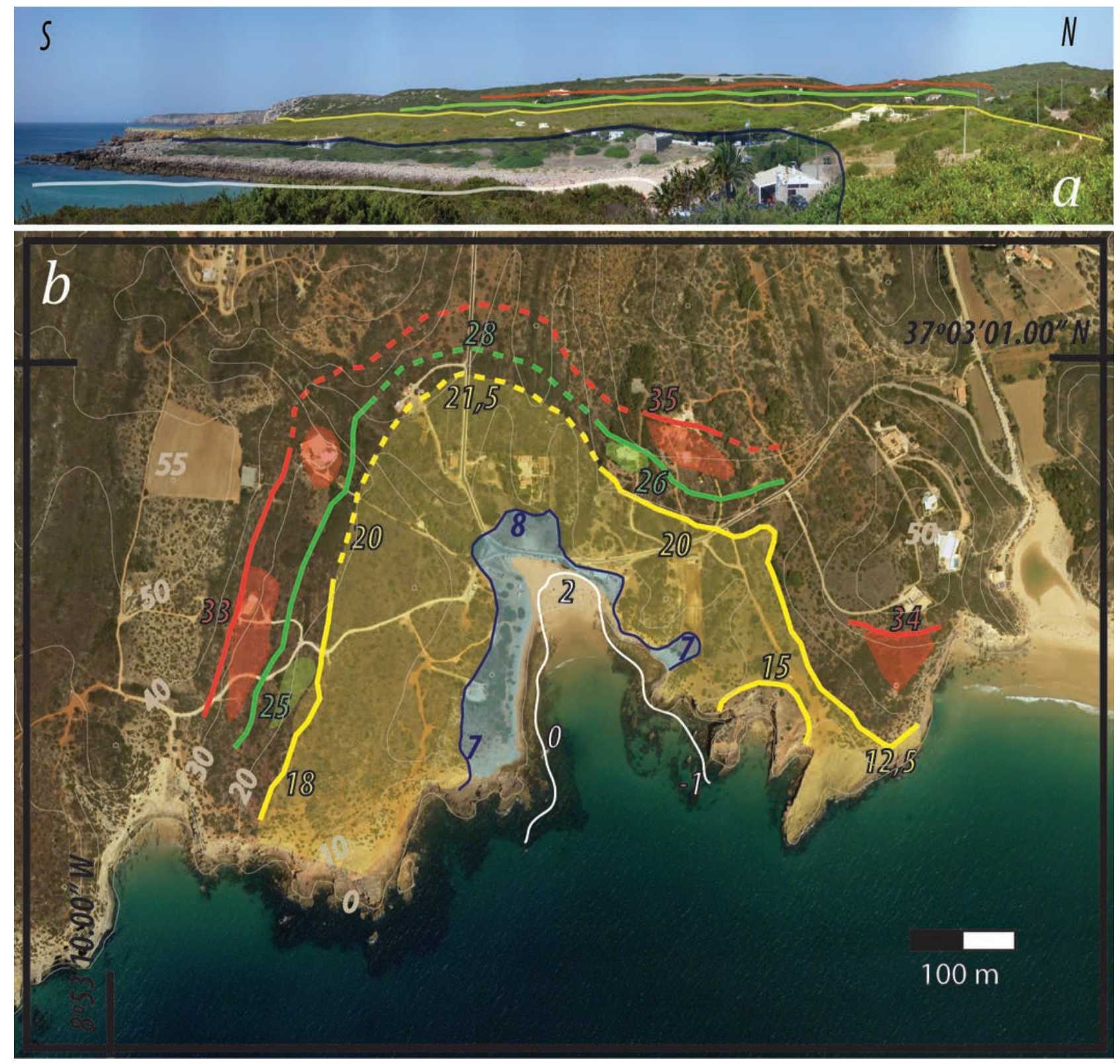

Figure 4. Map identifying the marine terrace at the Ingrina site. a) Panoramic view from east and terrace perspective. b) Inner edge and terrace map. Terraces are mapped in transparent colors and the inner edges in solid line when visible and dashed line when inferred. White-T0 (modern); blue-T1; yellow-T2; green-T3; red-T4. Inner edges elevations in meters are provided. Topography contours lines each $10 \mathrm{~m}$.

gently rising to an internal section where an inner-edge is recognized at $20-21 \mathrm{~m}$. Along the inner-edge or paleoshoreline, conglomerates of quartz pebbles testify to the presence of the paleo-beach face. No sediments were identified above this level, but scattered quartz pebbles are preserved.

We have interpreted these 3 surfaces as morphological segments of a single wave-cut platform. In general, the surface ramps up towards inland as three distinct morphologic sections: a generally flat or lowgradient section near the outer-edge that ranges between about $12 \mathrm{~m}$ and $16 \mathrm{~m}$ elevation; a moderately sloping middle section at circa 16-18 m elevation, and a higher more steeply sloping surface that ramps up to the inner-edge of the terrace at $21 \mathrm{~m}$ elevation.
Collectively, we designate this sequence as $\mathrm{T} 2$, or the second emergent marine terrace at Ingrina. The inner-edge, or shoreline angle, which is locally buried by colluvium, reaches maximum elevations of 20-21 m near the shoreward cuspate part of the paleo-bay, similar to the modern shoreline, which reaches its maximum elevation at the shoreward inner-edge of the bay (green line in Figure 4).

Higher surfaces, which correspond to older marine terraces, are also recognized at Ingrina, inferred from slope changes at about $26 \mathrm{~m}, 33 \mathrm{~m}, 37 \mathrm{~m}$ and $45 \mathrm{~m}$, but further work is needed to adequately identify shorelines, characterize their elevations and their degree of preservation. Nevertheless, their presence, along with the well-preserved terraces at $8 \mathrm{~m}$ and $21 \mathrm{~m}$ (Figure 9), 
and the higher broad abrasion surfaces at elevations higher than $100 \mathrm{~m}$, indicate long-term uplift of a rising coastline.

\subsubsection{Furnas}

At Furnas, located in the southern coastline $2 \mathrm{~km}$ east of Ingrina and $10 \mathrm{~km}$ to the southeast of Castelejo beach (presented in 4.2.3), a narrow raised bench at $2 \mathrm{~m}$ elevation is present at the base of a $40 \mathrm{~m}$-high cliff (Figure 2 and 5). Additionally, at this site, there are two levels of sea caves and associated beach sediments at different elevations that we interpret as additional evidence for the presence of the terrace $\mathrm{T} 1$ along the southern coast.

Of note at this location is that the modern sea cave notch is actively being cut at about $3 \mathrm{~m}$ below m.s.l., probably because this is along a prominent section of the coast and inner edges tend to be lower at promontories; and also because locally the rock could be more resistant to erosion due to its hardness. Thus, paleo-sea level features need to be interpreted according to this relative reference frame.

The raised bench corresponds to a terrace highlighted by a narrow abrasion platform and a sea cave/notch at $2 \mathrm{~m}$, and another sea cave/notch at about $3.8 \mathrm{~m}$ elevation (Figure 5). Both sea caves/notches are

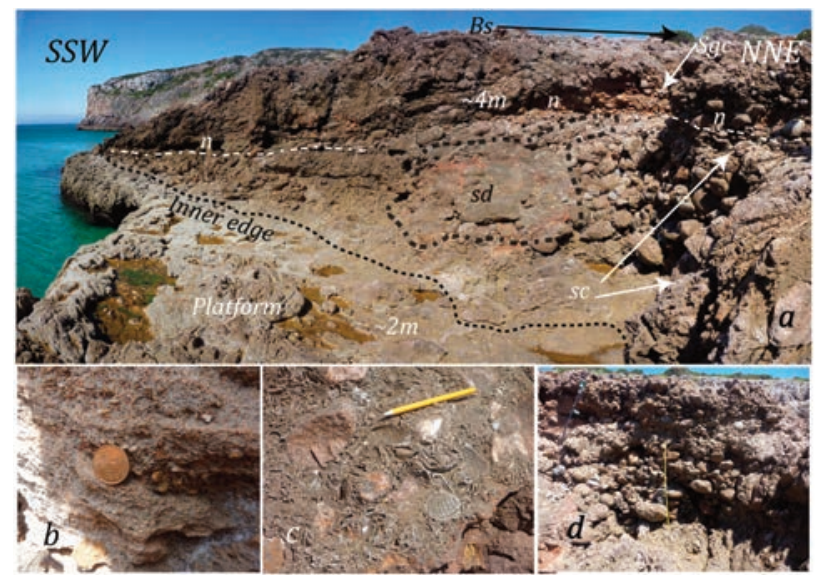

Figure 5. Marine terrace at Furnas site. Location is given in Figure 2. a) Perspective of the terrace: An abrasion platform and an inner edge are recognized at $\sim 2 \mathrm{~m}$ elevation; a notch level ( $\sim 4 \mathrm{~m}$ elevation) and sea cave (between $\sim 4$ and $\sim 2$ m elevation)are also indicated; A small surge channel (Sgc) is identified, suggesting that the sand deposit (sd) that covers the coarser deposits is correlated with the beach sand deposit (Bs) present at $\sim 8 \mathrm{~m}$ elevation. b) detail of beach sand unit; c) detail of sand deposit; $d$ ) sea cave filled by coarse deposits.

filled with cemented coarse marine sediments, with cobles ranging from 5 to tens of centimeters (Figure 5b). A cemented sand deposit with marine shells (mussels) is present, covering the coarser sediments, at elevations ranging from $2 \mathrm{~m}$ to $4 \mathrm{~m}$. This sand deposit has a depositional shape comparable to a fan, and may be interpreted as a small paleo surge channel. The sands with marine shells indicate a submarine proximity to a paleo beach and a likely paleo intertidal environment presently at the $\sim 4 \mathrm{~m}$ elevation. These features are approximately $5-7 \mathrm{~m}$ above their modern counterparts, so we infer these to correlate to the T1 terrace surface at Ingrina, which is at a comparable elevation above its modern counterpart.

Remains of beach deposits with small pebbles, shells and cross bedding are also preserved at $8 \mathrm{~m}$ elevation (Figure $5 \mathrm{c}$ ) and probably correspond to a paleo beach in the mouth of the paleo surge channel that is present here. For now, we correlate these marine remnants with the highest $\mathrm{T} 1$ terrace elements at the Ingrina site.

In summary, the modern shoreline notch at Furnas is located at about $3 \mathrm{~m}$ below sea level, and there are elevated notches at 2-4 m, indicating 5-7 m of relative difference for exposed rock erosional features. At the mouth of a small surge channel, littoral depositional features are preserved up to about $8 \mathrm{~m}$. Together, we interpret these features to represent different littoral elements of the same sea level high stand and correlate all of these with the T1 marine terrace at Ingrina.

\subsubsection{Castelejo}

Castelejo site is located in the western coastline at the base of a $120 \mathrm{~m}$ high cliff (Figures 2, 3c and 6). At Castelejo beach we only recognized one surface, which was referred by previous authors [Pereira 1990, Cabral 1995, Dias 2001]. This surface corresponds to a wave-cut platform cut into the Paleozoic schistose bedrock at 1.5 to $2 \mathrm{~m}$ elevation: the modern abrasion platform is therefore essentially reoccupying and retrimming an older surface, as evidenced by the preservation of a wave-cut platform locally capped by sediments. Overlying the abrasion platform, there are two conglomeratic layers separated by a thin beach sand layer [Figueiredo et al. 2010, 2011] overlain by strongly cemented aeolianites. Equivalent remnants of this surface and the capping sediments are also preserved at the Amoreira and Bordeira beach sites, also along the western coastline, 15 and 30 $\mathrm{km}$ farther north, respectively (Figure 3).

The upper unit, the aeolianite sequence, contains several paleosols and colluvial units (Figure 6), and therefore probably represents multiple periods of deposition on top of a paleo marine terrace and against a paleo-cliff during the late Pleistocene. The sequence is outcropping as a residual relief located 75 to $100 \mathrm{~m}$ seawards of the present active cliff. Marques [1997] calculated a maximum cliff retreat of $0.017 \mathrm{~m} / \mathrm{yr}$ for this specific location based on a 50 year period of observations. This rate is consistent with the average Holocene rate of cliff retreat 


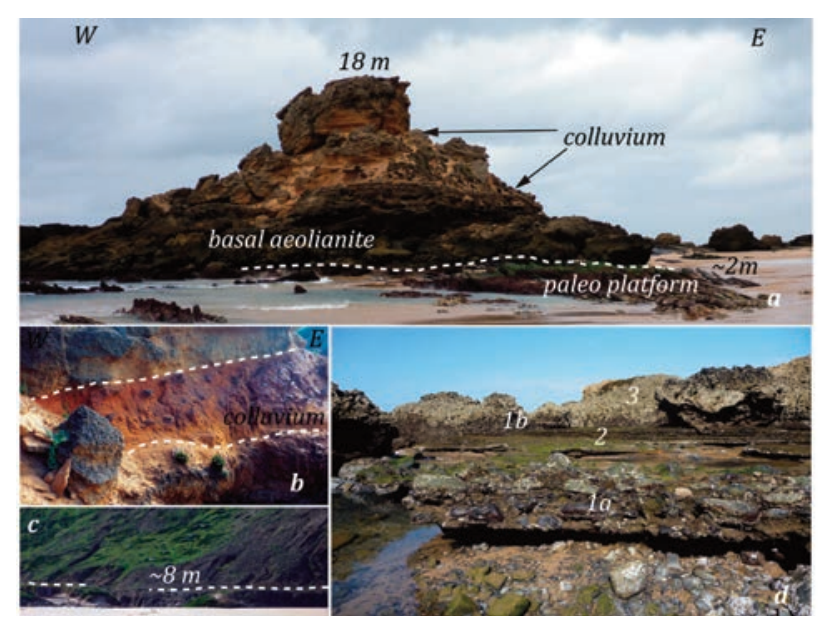

Figure 6. Marine terraces at the Castelejo site. Location is given in Figure 2. a) Perspective of the aeolianites unit which lays on top of a paleo wave-cut platform; b) Detail of a colluvium wedge with soil development inter bedded with aeolianites. c) fluvial terrace at $8 \mathrm{~m}$; d) Sedimentary sequence on top of the paleo platform: 1a-basal coarser unit; 2- sandy beach unit; 1b- upper coarser unit; 3-aeolianites.

for the last 4500-6000 years, when Holocene sea level stabilized. This observation also corroborates that the modern wave-cut platform has retrimmed an older one and has extended it inland.

Considering ages from other carbonate aeolianites from Portuguese coastal areas [Moniz 1992, Pereira and Angelucci 2004, Soares et al. 2006, Prudêncio et al. 2007], we assume that the consolidated aeolianites are most probably related with the last stages of the Würm glaciation ( MIS 4-3), or with the Last Glacial Maximum $(\sim$ MIS 2$)$ and consequently, the underlying beach sediments and platform should be older and possibly correlative of the MIS 5, most likely the last sub-stage, MIS $5 \mathrm{a}$.

Close to the beach, a small canyon cut into the schistose bedrock is incised in a flat erosional surface at 7-8 m elevation, which we assume to be a fluvial terrace that should be located very close to the mouth of this drainage. The base level correlated with this surface is likely to correspond to the sea level position that has generated T1. We conclude that this fluvial terrace should correspond to the final section of this canyon, located near the shore, and most likely re-activated during the Holocene transgression and cliff retreat, and re-incised to its actual position (Figure 6c).

We consider that the recognized abrasion surface may correspond to a lower (seaward) section of the terrace $\mathrm{T} 1$, and the fluvial terrace as secondary evidence for a higher inner edge elevation, and so we tentatively correlate it to the T1 surface at the Furnas and Ingrina sites.

\subsubsection{Carrapateira}

Carrapateira is located $10 \mathrm{~km}$ north of Castelejo beach, and is a promontory cut into Mesozoic (mainly Jurassic) limestones along the west coast (Figure 2). Be-

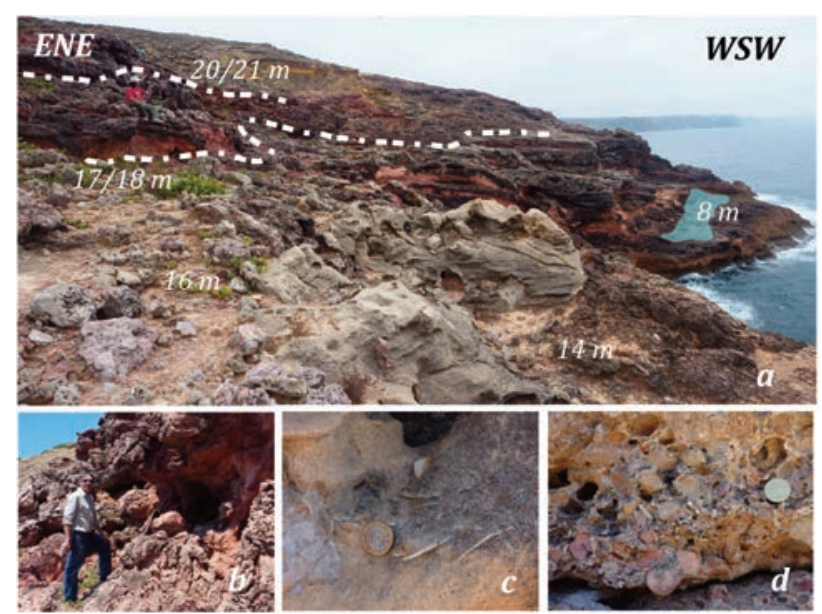

Figure 7. Panoramic view of Carrapateira, southern section Carrapateira site: a) T2 terrace perspective ; b) notch at 20/21 m elevation c) detail of beach sand with imbricate shells; d) basal section of the sedimentary T2 sequence, laying on top of the wave-cut platform with coarser sediments at $14 \mathrm{~m}$ elevation.

cause the cliff retreat rate in the western coast is slower in this area [Marques, 1997] than in the rest of the western coast, it is expected to be a reasonably good site to preserve $\mathrm{T} 1$ and $\mathrm{T} 2$ terraces. Plus, it presents lithological and morphological similarities with the southern coast and is therefore the ideal site along the western coastline to compare with the marine terraces identified along the southern coastline. However, because the west coast is more exposed to high energy waves than the southern coast, resulting in a broader zone of wave erosion, $\mathrm{T} 1$ along this section is poorly preserved and generally difficult to survey. Paleo features, such as raised notches, raised marine sediments, and inner edges were recognized in a discontinuous pattern along a $3 \mathrm{~km}$ long section of coast. Locally, at the cliff base, remains of small spurs at about $12 \mathrm{~m}$ elevation are present that provide additional evidence of a raised abrasion platform.

Along the south section of Carrapateira, the outeredge of a poorly expressed, narrow wave-cut platform with irregular morphology is exposed in a cliff face at 13-14 m elevation. This surface is covered by coarse, round pebbles and sandy beach sediments, confirming its marine origin (Figure 7). The irregularity of the wave cut rock surface probably indicates that these are surge channels, similar to those present at many sections of the modern coast. In the same vicinity and at generally similar elevations, paleo-sea caves were also identified. The wave-cut platform ramps up to 17-19 m elevation where a thin layer of beach sediments and cemented aeolianites are also present. Notches and sea caves were also recognized at these higher elevations, which generally are larger than the ones at about 14 m elevation.

At the northern section of the promontory (Figure 8 ), the $13-14 \mathrm{~m}$ surface is substantially eroded, but 


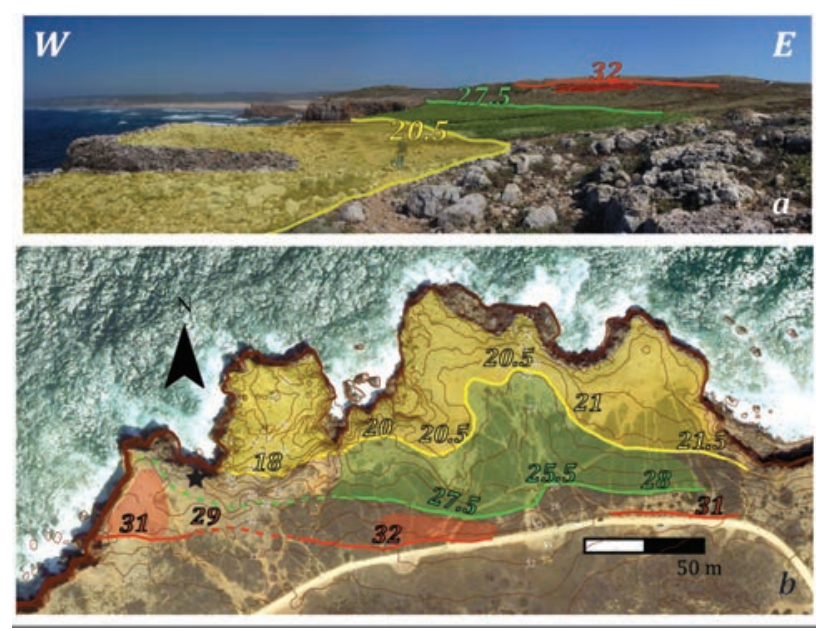

Figure 8. Panoramic view of Carrapateira, northern section Carrapateira site, showing the northern section of the promontory. Marine terrace mapping: a) panoramic view and terrace perspective (site where picture was taken marked by "star" at b); b) inner edge and terrace map. For each terrace, the inner edge is mapped, solid line when visible, dashed line when inferred; Yellow-T2; Green-T3; Red-T4. Inner edge elevations are provided in meters. T3 and T4 are not discussed in detail in this work.

the $17-19 \mathrm{~m}$ surface is very well represented and may reach a width of $20 \mathrm{~m}$ to $30 \mathrm{~m}$, likely to correspond to a marine terrace tread area, i.e., to a near-shore zone of marine abrasion. It is locally covered by cemented, gray to white aeolianites. This flat surface evolves into a smooth ramp to a slightly higher section where the inner-edge is well defined at $21 \mathrm{~m}$ elevation. We interpret these elements as sections of a marine terrace, and correlate this terrace with the T2 at the Ingrina site, which has similar surfaces and an inner-edge at similar elevations (Figure 9). Other higher surfaces with inneredges at about $26 \mathrm{~m}$ and $33 \mathrm{~m}$ were also recognized at Carrapateira promontory, which culminates in a higher, flat well-formed surface at about $40 \mathrm{~m}$ elevation that is capped by paleo and modern aeolianites, similar to what was identified at Ingrina site, but as mentioned earlier, they will not be interpreted in this work.

As mentioned above, the T1 terrace along the Carrapateira site is very difficult to recognize. Two benches were identified at elevations of $4 \mathrm{~m}$ and $8 \mathrm{~m}$, but both are covered by large boulders that were likely deposited by high energy events (storms and/or tsunamis). However, at Bordeira beach, immediately north of Carrapateira promontory, cemented beach sediments composed of rounded schist pebbles cover a wave-cut platform cut into the Paleozoic bedrock, and are in turn overlain by cemented aeolianites, similarly to what is observed at the Castelejo site (Figure $3 \mathrm{~d}$ ), so we considered this deposit as likely to be correlative of Castelejo terrace and therefore representative of the T1 terrace. This outcrop is usually buried by the modern beach sand and exposed only during extreme storm events.

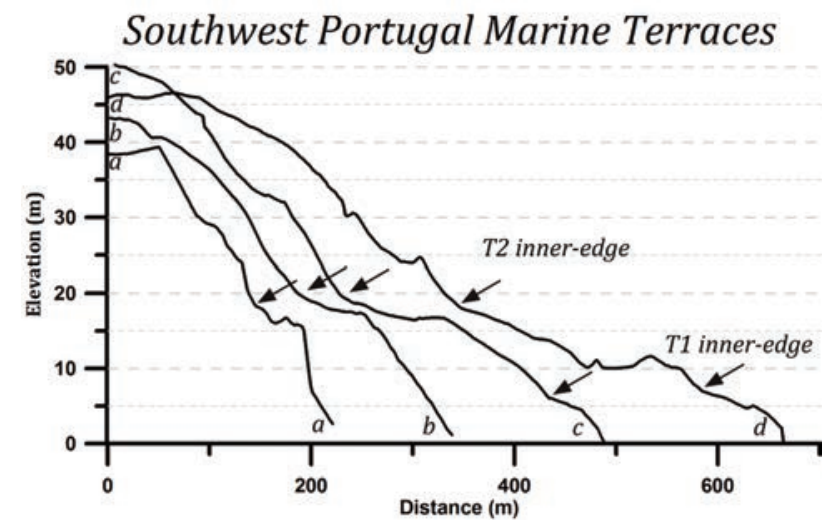

Figure 9. Southwest Portugal marine terraces topographic section profiles, surveyed with GPS- RTK: (a) North Carrapateira; (b) South Carrapateira; (c) Eastern Ingrina; (d) Western Ingrina. T2 inner edges are visible in all profiles at equivalent elevations and T1 inner edges are only visible at Ingrina profiles, due to erosion at Carrapateira.

\subsection{Historical seismicity and coastal deformation}

Southwest Portugal has not experienced any significant earthquakes generated by inland active structures for at least as long as there are historical records, that is, in the past 2000 years. However, this region has been affected by several large earthquakes generated from off-shore sources, the most significant being the 1st November, 1755 event. Other relevant historical earthquakes have also been reported for this region, such as the $382 \mathrm{AD}$ [Brito 1597] earthquake, referenced to have caused the submersion of three islands offshore of Sagres, but descriptions also suggest a macroseismic area extending along all of the Mediterranean coast, including Palestine, so the reliability of such reports is dubious.

There is still no consensus about what structure or structures were the sources for the 1755 earthquake, which was a complex earthquake with three distinct periods of shaking that are considered as sub-events and that possibly reflect a complex rupture pattern with rupture of multiple faults. Several structures are considered as plausible major candidates to have ruptured, such as the Marquês de Pombal, Horseshoe or Gorringe Bank faults. Considering their size, geometry, kinematic characteristics and distance to the shore, it is expected that along the coastline the crust would not suffer any significant vertical deformation. However, if some other fault located closer to the shoreline ruptured in this complex earthquake, some vertical movement may actually have occurred along the coastal region.

Despite all of the detailed descriptions about the 1755 earthquake and resulting effects at many places in southern Portugal, there is no specific mention or known description of relative sea level changes along this southwestern shoreline. This may be partially due 
to the fact that within 15 to 20 minutes after the earthquake, the coastal area was hit by a large tsunami, which destroyed all of the anthropogenic structures such as harbors, wharfs and other structures, so that people lost all sea level reference frames. Further, the tsunami was so powerful that it generated a large flood and debris field that may have masked any subtle changes. The only relevant report concerns the mention to a harbor at Aljezur, located about $5 \mathrm{~km}$ inland from the coast, which connected with the ocean through a deep river channel. Descriptions from a few years after the earthquake reported a decrease of the navigable depth of the channel [Lopes 1842]. However, at the mouth of this river, at Amoreira beach, no vertical change was identified in the Holocene sea level references (T0 in this work), so that a plausible explanation is that the river may have silted up due to the numerous landslides reported in the region as a result of the earthquake.

Hindson et al. [1999], based on foraminifera and ostracod assemblages from the sedimentary fill sequence of a fluvial valley at Boca do Rio, located near the southern coastline (Figure 2), inferred an abrupt change from a marine to a brackish environment in this valley at about 1800 to 1300 years ago. They interpreted this change as a consequence of the development of a sand dune barrier, which may have isolated the fluvial valley. However this environmental change may also be the consequence of a minor uplift event, preventing the ocean water from penetrating inland. Kortekaas and Dawson [2007] in their study of the 1755 tsunami, also studied a sedimentary fill near the coast at Sagres, $12 \mathrm{~km}$ to the west of Boca do Rio, and corroborate a change from a marine to a brackish environment, about 1700 years ago. In fact, a large earthquake is inferred for the area in $382 \mathrm{AD}$, as mentioned above, so an associated vertical deformation is an open hypothesis. Kortekaas and Dawson [2007] also inferred that after the 1755 earthquake and tsunami, this area was subjected to dryer and higher elevation depositional conditions, suggesting that minor uplift might have occurred.

\section{Discussion}

\subsection{Marine Terraces Correlation}

$\mathrm{T} 1$ is the lowest terrace recognized in the region (Figure 9). We identified distinct sections or segments for this single terrace at elevations starting from 1.5-2 m for the outer flat section, up to an inner edge at about $8 \mathrm{~m}$ elevation, with a similar morphology to the modern marine terrace. We recognized $\mathrm{T} 1$ in the west coast at Amoreira, Bordeira, Castelejo and in the south coast at Ingrina and Furnas, at consistent elevations.
$\mathrm{T} 2$ is the second terrace present in this region (Figure 9), and correlative sections of this terrace were identified along the west coast at Carrapateira, and along the south coast at Ingrina, exclusively in areas with limestone bedrock. These are areas which are more resistant to erosion and preserved from modern cliff retreat. We have identified the inner edge of this terrace at a consistent elevation of about $21 \mathrm{~m}$.

The best-preserved terrace sequence is at the Ingrina site (Figure 4), where several surfaces with multiple marine features are interpreted as a complete sequence of two marine terraces with shore-line angles at elevations of $8 \mathrm{~m}$ and $21-22 \mathrm{~m}$, respectively. At this site, paleo sea cliffs and remains of surfaces with inner edges at about $26 \mathrm{~m}, 33 \mathrm{~m}, 37 \mathrm{~m}$ and $45 \mathrm{~m}$ were also recognized, but details of these surfaces will not be described in this work. Ingrina is the key site for the interpretation of the regional marine terraces sequence for this region, as the terraces are well-preserved and morphologically exposed. We interpret their ages to range from late to middle Pleistocene, and this interpretation is corroborated by the presence of similar surfaces with the same elevations at other locations along the Southwest Portuguese coast, such as at the Furnas, Castelejo and Carrapateira sites (Figures 5, 6, 7 and 8).

\subsection{Terrace ages and interglacial interpretation}

During the Pleistocene climatic oscillations, sea level fluctuated between low stands (glacial times) and high stands (interglacial times). Only one of the sea level high stands during the past $130 \mathrm{ka}$ is interpreted to have been higher than current mean sea level, which was during the beginning of the last interglacial period, i.e. the MIS $5 \mathrm{e}$ (or MIS 5.5), the oldest of the 3 peaks $(5 \mathrm{a}, 5 \mathrm{c}$, and 5e) of interglacial MIS 5 [Shackleton and Opdyke 1973, Bloom et al. 1974, Siddall et al. 2006] (Figure 10). This higher peak was also a long lasting one, starting from about $128 \mathrm{ka}$ to $116 \mathrm{ka}$ [Muhs et al. 1994, Muhs et al. 2002a], so it should have generated a broad wave-cut platform and marine terrace.

Several studies have been concerned with the elevations of MIS 5e marine terrace features, and their corresponding age, at different locations around the world. The eustatic sea level at the time of MIS $5 \mathrm{e}$ has been estimated to be in the range of +2 to $+9 \mathrm{~m}$ [Hearty et al. 2007, Sidall et al. 2006, Pedoja et al. 2011] with a high probability to have reach $+6.6 \mathrm{~m}$ [Kopp et al. 2009]. These compilations have been derived from many sources and regions, implying the application of various geochronological methods to distinct paleo-sea features at different latitudes and in distinct coastal environments. This is discussed by Dutton et al. [2012], who also discuss the impact of glacial-hydro-isostatic 
processes induced by the weight of large ice sheets and water volume changes in the ocean basin promoting deformations in the earth surface, and consequently influencing the positions of the paleo-shorelines. These deformations occur with different intensity and rate according to their geographical proximity to the ice sheets and also with different timing accordingly with the ice sheet melting time and hydro-isostatic processes. Dutton et al. [2012] state that for MIS 5e, the relative sea level was not the same for everywhere on Earth, as the sea level response would not be synchronous, and consequently MIS 5e could have distinct time frames and different elevations for areas according to different glacial-isostatic responses to the ice sheets weight. Rockwell et al. [1989] commented about the correlation between paleo sea level references at near equatorial locations such as Barbados and New Guinea and their own observations for the southwest Californian and northwest Mexican coastline at middle latitudes, suggesting a worldwide variation in the relative sea-level of some meters, which if not taken into account then would have an implication on the estimating of vertical motions on a slowly rising coastline, such as Portugal.

In this work, we will primarily consider the MIS 5 sea level references for regions with oceanic rocky coasts at equivalent latitudes that are expected to be similar to the southwest Portuguese coast [Rockwell et al. 1994, Muhs et al. 1994, 2002b]. Thus, we will consider a eustatic sea level reference of +4 to $+6 \mathrm{~m}$ for the MIS 5e [Rockwell et al. 1989, 1994, Muhs et al. 2002b], of -2 to $-4 \mathrm{~m}$ for MIS $5 \mathrm{a}$ ( $80 \mathrm{ka}$ ) and of zero to $-2 \mathrm{~m}$ for MIS 5c (105 ka).

Due to global observations that indicate sea level was 4-10 $\mathrm{m}$ above the present mean sea level during the MIS 5e, we expect not only a broad wave-cut platform to have been generated, but also that the corresponding paleo morphology would be emergent, unless the coastal region of Portugal is significantly subsiding. Previous vertical motions studies conducted in Portugal have suggested that this area has been subjected to uplift since the Pliocene, although with a low rate of less than $0.2 \mathrm{~mm} / \mathrm{a}$ [Cabral 1995]. It is therefore expected that the more recent interglacial marine terraces should be at least locally preserved, and at elevations that are now higher than elevations at which they were originally formed. It is also expected that they should be well represented and preserved, unless the Holocene erosion rates are sufficiently high so as to have removed all lower terraces. Although the latter is clearly the case in some areas, the presence of significantly elevated marine terraces to $360 \mathrm{~m}$ (Fonte Santa), along with the deeply incised canyons and valleys in the Algarve region all support coastal emergence.
Thus, the presence of the MIS 5e terrace is expected to be preserved in SW Portugal, albeit only locally.

We have recognized two low terraces that are reasonably well preserved at four locations along the southwestern coast of Portugal, the T1 and T2 terraces with inner edge elevations at $8 \mathrm{~m}$ and $21 \mathrm{~m}$, respectively. Comparing these two terraces, the one which has a broader expression is the T2 terrace, where it was possible to us to identified 3 distinct subsections, interpreted as morphological segments of a single wave-cut platform. Also, T1 seems to have been cut into the T2 terrace. With this reasoning, we infer that T2 likely corresponds to MIS 5e and that T1 would then correspond to MIS $5 \mathrm{c}$ or MIS $5 \mathrm{a}$.

MIS $5 \mathrm{c}$ corresponds to a very short peak at 103$105 \mathrm{ka}$, which may have later been reoccupied by the longer MIS $5 \mathrm{a}$ highstand at $80 \mathrm{ka}$. Thus, the $5 \mathrm{c}$ terrace level is commonly not distinguishable from the 5 a terrace for regions of low uplift rate, as it has most commonly been cut out [Hanson et al. 1994, Muhs et al. 1994, 2002b, Kern and Rockwell 1992, Rockwell et al. 1994]. We therefore infer that $\mathrm{T} 1$ should correspond to the MIS 5a highstand, and that T1 terrace likely reoccupied or cut out the slightly older MIS $5 \mathrm{c}$ terrace section, which is not preserved.

Another factor that tentatively supports the correlation of the T1 and T2 levels to the MIS 5a and 5e global highstands is that their elevations and spacing are nearly identical to the well-dated MIS $5 \mathrm{a}$ and $5 \mathrm{e}$ terraces at localities in central and southern California [Hanson et al. 1994, Muhs et al. 2002, Kern and Rockwell 1992] northern Baja California, Mexico [Rockwell et al. 1989], and Tangier peninsula, Morocco along the Strait of Gibraltar [Abad et al. 2013]. Areas undergoing slightly high rates of uplift show that the elevation difference between these two terraces increases as their respective terrace elevations increase, as would be expected if paleo-sea level were similar [Hanson et al. 1994, Muhs et al., 2002b].

If our correlation is correct, then T2 has been uplifted approximately $13 \mathrm{~m}$ since the last interglacial (21 $\mathrm{m}$ minus the modern inner edge elevation $(+2 \mathrm{~m})$ and minus the assumed $+6 \mathrm{~m}$ at the time of formation). There are no references for the precise time and duration of the MIS 5e along the Portuguese coast. Data compilation analysis suggest that the last interglacial had an average duration from $130 \pm 2 \mathrm{ka}$ to $119 \pm 2 \mathrm{ka}$ [Hearty et al. 2007 and references within]. However, as abrasion terraces are cut during the entire length of the highstand, terraces ages should correspond to the end of the interglacial period. Speed and Chang [2004] recognized at Barbados abrasion terraces the latest MIS 5e peak, that lasted from $127 \mathrm{ka}$ to 120 or to $115 \mathrm{ka}$; 
Dabrio et al. [2010] through a prograding barrier claims a $10 \pm 2 \mathrm{ka}$ duration for a highstand during MIS $5 \mathrm{e}$ for the southeast Spain, but without presenting accurate ages for the interval; Muhs et al. [2011] through a fossil reef complex at Florida, identifies a peak that has likely started at $127 \mathrm{ka}$ and lasted until $114 \mathrm{ka}$, but with some uncertainties due to the reef characteristics. However, Muhs et al. [2002b], based upon high precision dating of solitary corals from the MIS 5 e terrace along the west coast of North America, suggest that the last interglacial peak lasted from $\sim 128 \mathrm{ka}$ to $116 \mathrm{ka}$ (and may have been double peaked). Thus, we considered that is very likely that the last MIS 5e peak lasted until 116ka and we infer the $13 \mathrm{~m}$ of uplift occurred after about $116 \mathrm{ka}$, yielding a long term uplift rate of $0.11 \pm 0.01 \mathrm{~mm} / \mathrm{a}$. If sea level had already begun to drop towards the end of MIS 5e time, then this rate will increase accordingly.

The sea level reference for the MIS $5 \mathrm{a}$, relative to the MIS 5e shoreline elevation, was $2 \mathrm{~m}$ to $4 \mathrm{~m}$ lower than the modern sea level, as determined for abrasion terraces along the west coast of North America [Muhs et al. 2002b, 2004].

Taking into consideration this $0.11 \pm 0.01 \mathrm{~mm} / \mathrm{a}$ for the last $80 \mathrm{ka}$, we should expect 8 to $10 \mathrm{~m}$ of uplift, meaning that the $80 \mathrm{ka}$ zero sea level reference should now stand at an elevation of $6 \mathrm{~m}$ to $8 \mathrm{~m}$. Thus, we consider that the $\mathrm{T} 1$ inner edge that is present at approximately $8 \mathrm{~m}$ elevation correlates to the MIS 5 a marine terrace. The lower surface section of T1, recognized mainly at Castelejo and Furnas, with some remains preserved and reoccupied by the modern wave-cut platform and beach, corresponds to the subtidal section of the marine terrace, exposed during MIS 4 and MIS 3, when it was probably covered by aeolianites.

If the southwest of Portugal is rising at this slow rate (Figure 10), we expect that other marine terraces, such as those that correspond to the MIS 7 and MIS 9 highstands, have been uplifted as well. In fact, we have already identified features that might correspond to their inner edges at elevations consistent with this rate, but further work is needed to characterize this sequence.

Additional marine terraces at higher elevations have been also recognized, although they are typically poorly preserved, towards the regional abrasion surface identified at 120-130 m elevation, which should be middle Pleistocene in age. Further work is needed, especially to constrain the age of the sediments and the age of the erosional surfaces when sediments are not present, to properly assess the long-term rates of vertical motion.

\subsection{Historical seismicity and marine terrace vertical de-} formation

Efforts were made to identify co-seismic evidence of large earthquakes that have affected this area, but no irrefutable evidence was found. Assuming the uplift rate for this area is $0.11 \pm 0.01 \mathrm{~mm} / \mathrm{a}$ as inferred, we would only expect a little more than $1 \mathrm{~m}$ of uplift for the entire Holocene, meaning that either the source (or sources) that are responsible for this vertical motion have long quiescence periods and have not ruptured since the modern sea level stabilized or that the resulting effects were so small, centimetric to decimetric scale, that they would not be differentiable in a high energy mesotidal environment coast such as SW Portugal.

It is possible that a small vertical motion has been

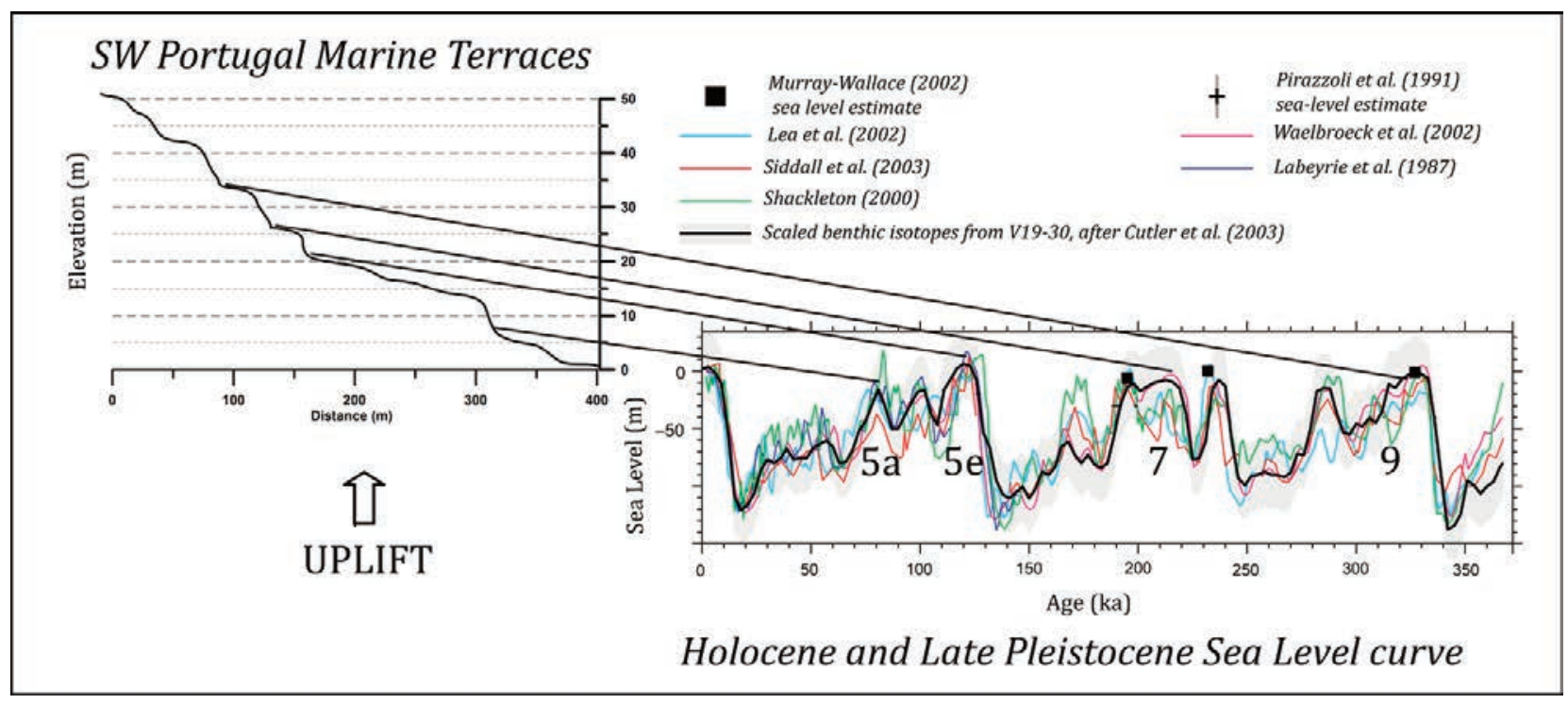

Figure 10. Schematic southwest Portugal marine terraces correlation with paleo-sea level estimates compiled from different studies: MIS 5a, MIS 5e, MIS 7, MIS 9 interglacials are identified (adapted from Siddall et al. [2006]). 
identified through interpretation of abrupt changes in the sedimentary fills of two fluvial valleys near the coastline (Boca do Rio and Martinhal, at Sagres), and that this may have happened twice, once following the $382 \mathrm{AD}$ earthquake and again following the 1755 earthquake. However, it is also possible that these environmental changes were partially due to the local perturbations caused by the tsunami flooding, local landsliding, or for other reasons.

The closest large active structure known in this region is the Marquês de Pombal thrust, a $70 \mathrm{~km}$ long structure located circa $100 \mathrm{~km}$ west-southwest from Sagres, and motion on this fault is not likely to have produced vertical motions at the coastline. Thus, if there was any vertical motion associated with these two historical earthquakes, it is likely to have been generated by a more local, currently unknown source.

\section{Conclusions}

We recognize several marine terraces along the southwest Portuguese coastline, with the lower two (T1 and T2) probably correlating to abrasion terraces cut during the last interglacial period of relative sea level highs (MIS 5). These two terraces were surveyed, and corresponding paleo sea level features were identified. Considering that the MIS 5e marine terrace should be the higher and better preserved of the two, we assumed that it corresponds to T2. If correct, this implies an uplift rate of $0.11 \pm 0.01 \mathrm{~mm} / \mathrm{a}$, which also corroborates the T1 marine terrace as the result of the MIS $5 \mathrm{a}$ marine high stand. A sequence of higher marine terraces is present, although they are poorly preserved, towards the higher regional abrasion surface, which according with to this rate, should be Middle Pleistocene in age ( 1 to $1,2 \mathrm{Ma}$ ).

This section of the Portuguese coastline is rising at rates not recognized for other regions in south Portugal, suggesting that an unknown local tectonic source be responsible for the long-term uplift of this region.

Acknowledgements. This work was funded by Fundação da Ciência e Tecnologia, through a PhD scholarship (SFRH/BD/36892/2007) attributed to Paula Marques Figueiredo and Research Project "Paleoseismological study of active faults in Mainland Portugal” (PTDC/CTE-GIN/66283/2006), co-financed by FEDER. The authors also are thankful to Filipe Rosas for providing Figure 1 and to Hector Perea whose comments significantly improved this manuscript.

\section{References}

Abad, M., J. Rodríguez-Vidal, K. Aboumaria, M.N. Zaghloul, L.M. Cáceres, F. Ruiz, Martínez-Aguirre, T. Izquierdo and S. Chamorro (2013). Evidence of MIS 5 sea-level highstands in Gebel Mousa coast (Strait of Gibraltar, North of Africa), Geomorphology,
182, 133-146.

Andrade, C., F. Marques, M.C. Freitas, R. Cardoso and P. Madureira (2002). Shore platform downwearing and cliff retreat in the Portuguese West Coast, in: Gomes, F.V. et al. Littoral 2002 6th International Symposium Proceedings: a multi-disciplinary Symposium on Coastal Zone Research, Management and Planning, 2,423-431.

Baptista, M.A. and J.M. Miranda (2009). Revision of the Portuguese catalog of tsunamis. Natural Hazards and Earth Systems Sciences, 1, 25-42.

Bartolome, R., E. Gràcia, D. Stich, S. Martínez-Loriente, D. Klaeschen, F. L. Mancilla, C.I. Iacono, J.J. Dañobeitia and N. Zitellini (2012). Evidence for active strike-slip faulting along the Eurasia-Africa convergence zone: implications for seismic hazards on the SW Iberian Margin. Geology, G33107.1.

Bloom, A.L., W.S. Broecker, J.M.A. Chappel, R.K. Mattews and K.J. Mesolella (1974) Quaternary sea-level fluctuations on a tectonic coast: New Th/U dates from the Huon Peninsula, new Guinea, Quaternary Reseacrh, 4, 185-205.

Bradley, W. C., and G.B. Griggs (1976). Form, genesis, and deformation of central California wave-cut platforms: Geol. Soc. of Am. Bull., 87, 433-449.

Brito, B. (1597). Monarchia Lusytana, Parte primeira que contém as historias de Portugal, desde a criação do mundo até o nascimento de nosso senhor Jesu Christo. Re-edition Craesbeeckiana Press (1690).

Cabral, J. (1995). Neotectónica em Portugal Continental, Mem. Nº31, Inst.Geol.Min., 265 pp.

Carrilho, F., P. Teves-Costa, I. Morais, J. Pagarete and R. Dias (2004). GEOALGAR Project: first results on seismicity and fault-plane solutions, Pure appl. Geophys., 161, 589-606.

Carrilho, F. (2005). Estudo da Sismicidade do Sudoeste de Portugal Continental, Master Dissertation, Physics Department, Lisbon University, 172 pp.

Costa, M., R. Silva and J. Vitorino (2001). Contribuição para o Estudo do Clima de Agitação Marítima na Costa Portuguesa. Instituto Hidrográfico, Lisboa.

Cunha, T.M., L.M. Matias, P. Terrinha, A.M. Negredo, F. Rosas, R.M.S. Fernandes and L.M. Pinheiro (2012). Neotectonics of the SW Iberia margin, Gulf of Cadiz and Alboran Sea: a reassessment including recent structural, seismic and geodetic data, Geoph. J. Int.1, 188 (3), 850-872, doi: $10.1111 /$ j.1365246X.2011.05328.x.

Custódio, S., S. Cesca and S. Heimann (2012). Fast Kinematic Waveform Inversion and Robustness Analysis: Application to the $2007 \mathrm{Mw} 5.9$ Horseshoe Abyssal Plain Earthquake Offshore Southwest Iberia, Bull. of the Seism. Soc. of Am., 102(1), 361- 
376, doi:10.1785/0120110125.

Dabrio, C.J., C. Zazo, A. Cabero, J.L. Goy, T. Bardají, C. Hillaire-Marcel, J.A. González- Delgado, J. Lario, P.G. Silva, F. Borja and A.M. García-Blázquez (2011). Millennial/ submillennial-scale sea-level fluctuations in western Mediterranean during the second highstand of MIS 5e. Quaternary Science Reviews 30, 335-346.

Dias, R. (2001). Neotectónica da Região do Algarve, Doctoral Dissertation, Lisbon University, 369 pp.

Dias, R. P. and J. Cabral (2002). Interpretation of recent structures in an area of cryptokarst evolution - neotectonic versus subsidence genesis. Geodinamica Acta, 15 (4), 233-248.

DeMets, C., R.G. Gordon, D.F. Argus and S. Stein (1994). Effect of recent revisions to the geomagnetic reversal time scale on estimates of current plate motions Geoph. Res. Lett., 21 (20), 2191, doi:10.1029/94GL02118 .

DeMets, C., R. Gordon and D. Argus (2010). Geologically current plate motions, Geophys. J. Int., 181, 180, doi: 10.1111/j.1365-246X.2009.04491.x

Duarte, J.C., F.M. Rosas, P. Terrinha, M.-A. Gutscher, J. Malavieille, S. Silva and L. Matias (2011). Thrustwrench interference tectonics in the Gulf of Cadiz (Africa-Iberia plate boundary in the north-east Atlantic): insights from analog models. Marine Geology 289, 135-149. doi:10.1016/j.margeo.2011.09.014

Duarte, J., F. Rosas, P. Terrinha, W. Schellart, D. Boutelier, M.-A. Gutscher and A. Ribeiro (2013). Are subduction zones invading the Atlantic? Evidence from the southwest Iberia margin. Geology, 41, 839-842. doi:10.1130/G34100.1

Dutton, A. and K. Lambeck (2012). Ice Volume and sea level during the last interglacial, Science, 337, 216219, doi:10.1126/science. 1205749.

Feio, M. (1951). A evolução do relevo do Baixo Alentejo e Algarve. Com. Serv. Geol. Portugal, t. XXXII, 2nd section, 303-447.

Fernandes, R.M.S., J.M. Miranda, B.M.L. Meijninger,M.S. Bos, L. Bastos, B.A.C. Ambrosius and R.E.M. Riva (2007). Surface velocity field of the Ibero-Maghrebian segment of the Eurasia-Nubia plate boundary. Geoph. J. Int. 169 (1), 315-324.

Figueiredo, P.M., J. Cabral and T. Rockwell (2010). Southwest Portugal Plio-Pleistocene tectonic activity studies: the S.Teotónio-Aljezur-Sinceira fault system and coastal tectonic uplift evidences. In: J. M. Insua and F. Martín González (eds.), Contribución de la Geología al Análisis de la Peligrosidad Sísmica, 1st Active Faulting and Paleoseismology Iberian Meeting Abstract Book, Sigüenza: 49-52.

Figueiredo, P. M., J. Cabral and T. K. Rockwell (2011).
Plio- Pleistocene Tectonic Activity in the Southwest of Portugal. In: C. Grützner, R. Pérez-López, T. Fernández-Steeger, I. Papanikolaou, K. Reicherter, P.G. Silva and A. Vött (eds.), 2nd INQUA-IGCP 567 International Workshop Proccedings, Vol. 2: Earthquake Geology and Archaeology: Science, Society and Critical facilities: 30-33.

Figueiredo, P.M. T. K. Rockwell and J. Cabral (in preparation) Plio-Pleistocene Marine terraces along the southwest Portugal: implications for a long term uplift.

GEBCO Digital Atlas, (2003). Centenary Edition of the GEBCO Digital Atlas, published on CD-ROM on behalf of the Intergovernmental Oceanographic Commission and the International Hydrographic Organization as part of the General Bathymetric Chart of the Oceans, British Oceanographic Data Centre, Liverpool, U.K.

Geissler, W.H., L. Matias, F. Stich, F. Carrilho, W. Jokat, S.Monna, A. IbenBrahim, F. Mancilla, M.-A. Gutscher, V. Sallarès and N. Zitellini (2010). Focal mechanisms for sub-crustal earthquakes in the Gulf of Cadiz from a dense OBS deployment. Geoph. Res. Lett. 37, L18309.

Gràcia, E., J. Dañobeitia, J. Vergés and R. Bartolomé (2003a). Crustal architecture and tectonic evolution of the Gulf of Cadiz (SW Iberian margin) at the convergence of the Eurasian and African plates. Tectonics 22 (4), 1033-1052.

Gràcia, E., J. Dañobeitia, J. Vergés and P. Team (2003b). Mapping active faults offshore Portugal (36 degrees $\mathrm{N}$-38 degrees $\mathrm{N}$ ): implications for seismic hazard assessment along the southwest Iberian margin. Geology 31 (1), 83-86.

Gràcia, E., A. Vizcaino, C. Escutia, A. Asioli, A. Rodés, R. Pallàs, J. Garcia-Orellana, S. Lebreiro and C. Goldfinger (2010). Holocene earthquake record offshore Portugal (SW Iberia): testing turbidite paleoseismology in a slow-convergence margin. Quat. Sc. Rev. 29, 1156-1172.

Gutscher, M.A., S. Dominguez, G.K. Westbrook, P. Le Roy, F. Rosas, J.C. Duarte, P. Terrinha, J.M. Miranda, D. Graindorge, A. Gailler, V. Sallares and R. Bartolomé (2012). The Gibraltar subduction: A decade of new geophysical data. Tectonophysics, 574-575, 72-91.doi.org/10.1016/j.tecto.2012.08.038

Hanson, K. L., W. R. Wesling, W. R. Lettis, K. I. Kelson, and L. Mezger (1994). Correlation, ages, and uplift rates of Quaternary marine terraces, south-central California, in Alterman, I.B., McMullen, R.B., Cluff, L.S., and Slemmons, D.B. (eds.), Seismotectonics of the Central California Coast Ranges: Geol. Soc. of Am. Sp. Paper 292, 45-72. 
Hearty, P., J. Hollin, A.C. Neumann, M. O’Leary and M. McCulloch (2007). Global sea-level fluctuations during the Last Interglaciation (MIS 5e), Quaternary Science Reviews, 26 (17-18), 2090-2112.

Hindson, R., C. Andrade and R. Parish (1999).A microfaunal and sedimentary record of environmental change within the late Holocene sediments of Boca do Rio (Algarve, Portugal). Geologie en Mijnbouw, 77, 311-321.

I.G.E.O.E - Instituto Geográfico do Exército, Carta Militar de Portugal, série M888, .1/25 000 scale.

I.H. , Instituto Hidrográfico, Divisão de Oceanografia, Portugal Batimetry.

Johnston, A. (1996). Seismic moment assessment of earthquakes in stable continental regions-III. New Madrid 1811-1812, Charleston 1886 and Lisbon 1755,” Geophys. J. Int., 126, 314-344.

Kern, J.P. and T.K. Rockwell (1992). Chronology and deformation of Quaternary marine shorelines, San Diego County, California: in Quaternary Coasts of the United States: Marine and Lacustrine Systems: Society of Economic Paleotologists and Mineralogists Special Publication.No. 48, 377-382.

Kopp, R.E., F.J. Simons, J.X. Mitrovica, A.C. Maloof and M. Oppenheimer (2009). Probabilistic assessment of sea level during the last interglacial stage. Nature 462, 863-868.

Kortekaas, S., and A.G. Dawson (2007).Distinguish tsunami and storm deposits: An example from Martinhal, SW Portugal, Sedimentary Geology, 200, 208-221.

Laughton, A.S., R.B. Whitmarsh, J.S.M. Rusby, M.L. Somers, J. Revie, B.S. McCartney and J.E. Nafe (1972). A continuous East-West fault on the AzoresGibraltar ridge. Nature 237, 217-220.

Lopes, F. (2002) Análise tectono-sedimentar do Cenozoico da margem Algarvia. Doctoral Dissertation, Coimbra University.

Lopes, J.B.S. (1842) Corografia ou Memória Económica, Estatística e Topográfica do Reino do Algarve, $528 \mathrm{pp}$.

Marques, F.M.S.F. (1997). As arribas do Litoral do Algarve Dinâmica - processos e mecanismos. Doctoral Dissertation, Lisbon University, 560 pp.

Martínez-Loriente, S., E. Gràcia, R. Bartolomé, V. Sallarés, C. Connors, H. Perea, C. Iacono, D. Klaeschen, P. Terrinha, J. Dañobeitia and N. Zitellini (2013). Active deformation in old oceanic lithosphere and significance for earthquake hazard: Seismic imaging of the Coral Patch Ridge area and neighboring abyssal plains (SW Iberian Margin). Geochem. Geophys. Geosyst., 14, doi:10.1002/ggge.20173.

Martínez Solares, J., and A. López Arroyo (2004). The great historical 1755 earthquake, effects and damage in Spain, J. Seism. 8, 275-294.

Manuppella, G. (Coord.) (1992). Carta Geológica da Região do Algarve, 1/100 000 scale., Serviços Geológicos de Portugal.

Moniz, C. (1992)-Análise de Fracturação. Exemplos de Aplicação nas Dunas Consolidadas de Oitavos e Praia da Aguda. Master thesis, Lisbon University, 172 pp.

Muhs, D.R., G.L. Kennedy and T.K. Rockwell (1994). Uranium-series Ages of Marine terrace Corals from the Pacific of North America and Implications for Last- Interglacial Sea Level History, Quaternary Research, 42, 72-87.

Muhs, D.R., K.R. Simmons and B. Steinke (2002a). Timing and warmth of the last interglacial period: New U-series evidence from Hawaii and Bermuda and a new fossil compilation for North America. Quaternary Science Reviews (21) 1355-1383.

Muhs, D. R., K.R. Simmons, G. L. Kennedy and T. K. Rockwell (2002b). The last interglacial period on the Pacific Coast of North America: Timing and paleoclimate, Geol. Soc. of Am. Bull. 114, 569-592.

Muhs, D.R., K.R. Simmons, R.R. Schumann and R.B. Halley (2011). Sea-level history of the past two interglacial periods: new evidence from U-series dating of reef corals from south Florida, Quaternary Science Reviews, 30, 570-590.

Nocquet, J. M., and E. Calais (2004). Geodetic measurements of crustal deformation in the Western Mediterranean and Europe, Pure Appl. Geophys., $161,661-681$

Pedoja, K., L. Husson, V. Regard, P.R. Cobbold, E. Ostanciaux, M.E. Johnson, S. Kershaw, M. Saillard, J. Martinod, L. Furgerot, P. Weill and B. Delcaillau (2011). Relative sea-level fall since the last interglacial stage: Are coasts uplifting worldwide?, Earth Sc.Rev. 108 (1-2), 1-15.

Pereira, A.R. (1990). A plataforma Litoral do Alentejo e Algarve Ociedental. Estudo de geomorfologia. Doctoral Dissertation, Lisbon University 450 pp.

Pereira, A.R., and D. Angelucci (2004). Formações dunares no litoral português, do final do Plistocénico e inícios do Holocénico, como indicadores paleoclimáticos e paleogeográficos, in Evolução geohistórica do litoral português e fenómenos correlativos. Geologia, História, Arqueologia e Climatologia, Universidade Aberta, 221-256.

Pereira, R., and T. Alves (2011) Post-rift compression on the SW Iberian Margin (eastern North Atlantic): a case for prolonged inversion in the ocean-continent transition zone. Journal of the Geological Society, 168, 1249-1263. 
Pereira, R., and T. Alves (2013) Crustal deformation and submarine canyon incision in a Meso-Cenozoic firstorder transfer zone (SW Iberia, North Atlantic Ocean). Tectonophysics, 601, 148-162.

Prudêncio, M.I., R. Marques, L. Rebelo, G.T. Cook, G.O. Cardoso, P. Naysmith, S.P.H.T. Freeman, D. Franco, P. Brito and M.I. Dias (2007). Radiocarbon and Blue Optically Stimulated Luminescence chronologies of the Oitavos Consolidated Dune (Western Portugal), Radiocarbon, V. 49 (2), 1145-1151.

Ribeiro, A. (2002). Soft Plate and Impact Tectonics, Springer, 324 p. ISBN-3540679634.

Ribeiro, A., J. Cabral, R. Baptista and L. Matias (1996). Stress pattern in Portugal mainland and the adjacent Atlantic region, West Iberia. Tectonics 15 (2), 641-659.

Rockwell, T.K., D.R. Muhs, G.L. Kennedy, S. Wilson, M.E. Hatch and R. Klinger (1989). Uranium-series ages, faunal correlations and tectonic deformation of marine terraces within the Agua Blanca fault zone at Punta Banda, northern Baja California, Mexico: in P.L. Abbott (ed.), Geologic Studies in Baja California, Soc. Econ. Paleon. and Min. Book 63, 1-16.

Rockwell, T., P. Vaughan, F. Bickner and K.L. Hanson, (1994). Correlation and age estimates of soils developed in marine terraces across the San Simeon fault zone, central California: in Alterman, I.B., McMullen, R.B., Cluff, L.S., and Slemmons, D.B., eds., Seismotectonics of the central California Coast Ranges, Boulder, CO, Geological Society of America Special Paper 292, 151-166.

Rosas, F.M., J.C. Duarte, M.C. Neves, P. Terrinha, S. Silva, L. Matias, E. Grácia and R. Bartolomé (2012). Thrust-wrench interference between major active faults in the Gulf of Cadiz (Africa-Eurasia plate boundary, offshore SW Iberia): Tectonic implications from coupled analog and numerical modeling, Tectonophysics, doi:10.1016/j.tecto.2012.04.013

Roque, C. (2007). Tectonostratigrafia do Cenozóico das margens continentais Sul e Sudoeste portuguesas: um modelo de correlação sismostratigráfica, Doctoral Dissertation, Lisbon University.

Sartori, R., L. Torelli, N. Zittelini, D. Peis and E. Lodolo (1994) Eastern segment of the Azores-Gibraltar line (Central- Eastern Atlantic): an oceanic plate boundary with diffuse compressional deformation, Geology, 22, 555-558.

Serpelloni, E., G. Vannucci, S. Pondrelli, A. Argnani, G. Casula, M. Anzidei, P. Baldi and P. Gasperini (2007). Kinematics of the Western Africa-Eurasia plate boundary from focal mechanisms and GPS data. Geoph. J. Int., 169(3), 1180-1200.

Shackleton, N., and N. Opdyke (1973). Oxygen isotope and palaeomagnetic stratigraphy of equatorial $\mathrm{Pa}$ cific core V28-238: oxygen isotope temperatures and ice volumes on a 105 and 106 year scale. Quaternary Research 3, 39-55.

Siddall, M., J. Chappell and E.-K. Potter (2006). Eustatic Sea Level During Past Interglacials, in "the climate of past interglacials”, Sirocko F., Litt M., Claussen, M., Sanchez-Goni, F. (eds) Elsevier, Amsterdam.

Silva, S., M. Romsdorf, L. Matias, W. H. Geissler, P. Terrinha, F. Carrilho and Nearest Working Group (2010) Characterization of the seismicity in the Gulf of Cadiz based on eleven month monitoring by the NEAREST OBS network., Geoph. Res. Abstr.12, EGU2010-11554.

Soares, A.M.M., C.Moniz and J. Cabral (2006). The consolidated Dune of Oitavos (West of cascais-Lisbon Region)-its dating by the Radiocarbom Method, Comunicações Geológicas, 13, 105-118.

Speed, R.C., and H. Cheng (2004) Evolution of marine terraces and sea level in the last interglacial, Cave Hill, Barbados, Geological Society of America Bulletin, 116(1-2), 219-232.

Stich, D., E. Serpelloni, F.L. Mancilla and J. Morales (2006). Kinematics of the Iberia-Maghreb plate contact from seismic moment tensors and GPS observations, Tectonophysics, 426, 295-317.

Terrinha, P. (1998). Structural Geology and Tectonic Evolution of the Algarve Basin, South Portugal. Department of Geology, University of London, London.

Terrinha, P., L.M. Pinheiro, J.-P. Henriet, L. Matias, M.K. Ivanov, J. H. Monteiro, A. Akhmetzhanov, A. Volkonskaya, T. Cunha, P. Shaskin and M. Rovere (2003). Tsunamigenic-seismogenic structures, neotectonics, sedimentary processes and slope instability on the southwest Portuguese Margin, Marine Geology, 195, 55-73.

Terrinha, P., L. Matias, J. Vicente, J. Duarte, J. Luis, L. Pinheiro, N. Lourenço, S. Diez, F. Rosas, V. Magalhães, V. Valadares, N. Zitellini, C. Roque, L.M. Victor and Team M.A.T.E.S.P.R.O. (2009). Morphotectonics and strain partitioning at the Iberia-Africa plate boundary from multibeam and seismic reflection data. Marine Geology 267 (3-4), 156-174.

Villamor, P., R. Capote, M.W. Stirling, M. Tsige, K.R. Berryman, J.J. Martínez-Dias and F. MartínGonzález (2012). Contribution of active faults in the intraplate area of Iberia to seismic hazard: The Alentejo- Plasencia Fault, Journal of Iberian Geology, 38(1), 85-111.

Wright, L.W. (1970). Variation in the level of the Cliff/Shore platform junction along the south coast of great Britain, Marine Geology, 9, 347-353. 
Wziatek, W., M. Vousdoukas and P. Terefenko (2011) Wave-cut notches along the Algarve coast, S. Portugal: Characteristics and formation mechanisms, J. of Coast. Res., Sp. Iss. 64, 855-859.

Zitellini, N., L.A. Mendes, D. Cordoba, J. Danobeitia, R. Nicolich, G. Pellis, A. Ribeiro, R. Sartori, L. Torelli, R. Bartolomé, G. Bortoluzzi, A. Calafato, F. Carrilho, L. Casoni, F. Chierici, C. Corela, A. Correggiari, B. Della Vedova, E. Gràcia, P. Jornet, M. Landuzzi, M. Ligi, A. Magagnoli, G. Marozzi, L. Matias, D. Penitenti, P. Rodriguez, M. Rovere, P. Terrinha, L. Vigliotti and A. Zahinos Ruiz (2001). Source of 1755 Lisbon earthquake and tsunami investigated. Eos Transactions, Am. Geoph. Un. 82 (26), 290-291.

Zitellini, N., M. Rovere, P. Terrinha, F.Chierici, L. Matias and Bigsets Team (2004). Neogene through Quaternary tectonic reactivation of SW Iberian passive margin. Pure and Applied Geophysics 161 (3), 565-587.

Zitellini N., E. Gracia, L. Matias, P. Terrinha, M.A. Abreu, G. DeAlteriis, J.P. Henriet, J.J. Danobeitia, D.G. Masson, T. Mulder, R. Ramella, L. Somoza and S. Diez (2009). The quest for the Africa-Eurasia plate boundary west of the Strait of Gibraltar, Earth and Pl. Sc. Lett., 280(1-4), 13-50.

\footnotetext{
${ }^{\star}$ Corresponding author: Paula M. Figueiredo, Instituto Dom Luiz, IDL, Lisbon, Portugal; Lisbon University, Science Faculty, Geology Department, Lisbon, Portugal; pmfigueiredo@fc.ul.pt

(C) 2013 by the Istituto Nazionale di Geofisica e Vulcanologia. All rights reserved.
} 